\title{
Review
}

\section{Epidemiology, Diagnosis, and Control of Canine Infectious Cyclic Thrombocytopenia and Granulocytic Anaplasmosis: Emerging Diseases of Veterinary and Public Health Significance}

\author{
Farhan Ahmad Atif ${ }^{1, *}$, Saba Mehnaz ${ }^{1,2}{ }^{\oplus}$, Muhammad Fiaz Qamar ${ }^{3}$, Taleeha Roheen ${ }^{4}$, Muhammad Sohail Sajid ${ }^{2}$, \\ Syed Ehtisham-ul-Haque ${ }^{3}\left(\mathbb{D}\right.$, Muhammad Kashif ${ }^{1}$ and Mourad Ben Said ${ }^{5,6, *(1)}$
}

1 Medicine Section, Department of Clinical Sciences, College of Veterinary and Animal Sciences, Jhang, Sub-Campus University of Veterinary and Animal Sciences, Lahore 54600, Pakistan; sabamehnaz2012@gmail.com (S.M.); muhammad.kashif@uvas.edu.pk (M.K.)

2 Department of Parasitology, Faculty of Veterinary Science, University of Agriculture, Faisalabad 38000, Pakistan; drsohailuaf@uaf.edu.pk

3 Department of Pathobiology, College of Veterinary and Animal Sciences, Jhang, Sub-Campus University of Veterinary and Animal Sciences, Lahore 54600, Pakistan; fiaz.qamar@uvas.edu.pk (M.F.Q.); ehtishamsyed@uvas.edu.pk (S.E.-u.-H.)

4 Department of Chemistry (Biochemistry), University of Sargodha, Sargodha 40100, Pakistan; taleeharoheen@yahoo.com

check for updates

Citation: Atif, F.A.; Mehnaz, S.; Qamar, M.F.; Roheen, T.; Sajid, M.S.; Ehtisham-ul-Haque, S.; Kashif, M.; Ben Said, M. Epidemiology, Diagnosis, and Control of Canine Infectious Cyclic Thrombocytopenia and Granulocytic Anaplasmosis: Emerging Diseases of Veterinary and Public Health Significance. Vet. Sci. 2021, 8, 312. https://doi.org/ $10.3390 /$ vetsci8120312

Academic Editors: Fabrizio Bertelloni and Patrick Butaye

Received: 7 September 2021

Accepted: 30 November 2021

Published: 8 December 2021

Publisher's Note: MDPI stays neutral with regard to jurisdictional claims in published maps and institutional affiliations.

Copyright: () 2021 by the authors. Licensee MDPI, Basel, Switzerland. This article is an open access article distributed under the terms and conditions of the Creative Commons Attribution (CC BY) license (https:// creativecommons.org/licenses/by/ $4.0 /)$.
5 Higher Institute of Biotechnology of Sidi Thabet, University of Manouba, Manouba 2010, Tunisia

6 Laboratory of Microbiology at the National School of Veterinary Medicine of Sidi Thabet, University of Manouba, Manouba 2010, Tunisia

* Correspondence: farhan.atif@uvas.edu.pk or atifvet_2000@yahoo.com (F.A.A.); bensaidmourad83@yahoo.fr or mourad.bensaid@isbst.uma.tn (M.B.S.); Tel.: +92-47-7671270 (F.A.A.); +216-58-964147 (M.B.S.)

\begin{abstract}
This review highlights the diagnostic methods used, the control strategies adopted, and the global epidemiological status of canine cyclic thrombocytopenia and granulocytic anaplasmosis at the animal-human interface. Canine anaplasmosis is an important worldwide disease, mainly caused by Anaplasma platys and A. phagocytophilum with zoonotic implications. A. platys chiefly infects platelets in canids, while A. phagocytophilum is the most common zoonotic pathogen infecting neutrophils of various vertebrate hosts. Diagnosis is based on the identification of clinical signs, the recognition of intracellular inclusions observed by microscopic observation of stained blood smear, and/or methods detecting antibodies or nucleic acids, although DNA sequencing is usually required to confirm the pathogenic strain. Serological cross-reactivity is the main problem in serodiagnosis. Prevalence varies from area to area depending on tick exposure. Tetracyclines are significant drugs for human and animal anaplasmosis. No universal vaccine is yet available that protects against diverse geographic strains. The control of canine anaplasmosis therefore relies on the detection of vectors/reservoirs, control of tick vectors, and prevention of iatrogenic/mechanical transmission. The control strategies for human anaplasmosis include reducing high-risk tick contact activities (such as gardening and hiking), careful blood transfusion, by passing immunosuppression, recognizing, and control of reservoirs/vectors.
\end{abstract}

Keywords: canine anaplasmosis; Anaplasma platys; Anaplasma phagocytophilum; diagnosis; epidemiology; control

\section{Introduction}

Anaplasmosis is a vector-borne disease that affects animals and humans worldwide [1]. It is a virulent non-contagious disease caused by strictly intracellular Gram-negative bacteria. These pathogens parasitize circulating blood cells (erythrocytes, monocytes, granulocytes, and platelets) [2]. Ticks act as natural vectors for Anaplasma species and play a key role in the biological multiplication of these bacteria in salivary glands and guts [3]. 
The genus Anaplasma (A.) consists of several classified species that have a valid taxonomic standing, namely, A. marginale, A. centrale, A. bovis, A. ovis, A. caudatum, and A. phagocytophilum [1]. Infectious canine cyclic thrombocytopenia and granulocytic anaplasmosis are two zoonotic diseases caused by A. platys and A. phagocytophilum, respectively, mainly affecting dogs and wild canids [1,2]. Anaplasma platys was first detected in a dog from Florida and frequently infects platelets. The disease is characterized by fever, anorexia, weight loss, lethargy, petechiae, pale mucous membranes, nasal discharge, bilateral uveitis, epistaxis, and lymphadenomegaly $[4,5]$. However, A. phagocytophilum primarily infects canine granulocytes (especially neutrophils) of a wide range of domestic and wild vertebrate hosts, as well as humans [6]. The first case of human granulocytic anaplasmosis was observed in 1994 in tangential blood smears from six human patients of Wisconsin and Minnesota, states of the United States of America [7]. However, the first case of A. platys infection in humans was reported in 1992 [8]. After this, the organism was detected in a veterinarian and two family members of dog owners [9,10]. In 2017, there were 5762 cases of human anaplasmosis in the U.S., and now, global distribution of cases has been achieved [11]. In addition, transplacental transmission has also been reported for A. phagocytophilum [12].

Infection with $A$. phagocytophilum in dogs is known as canine granulocytic anaplasmosis. The host range of $A$. phagocytophilum includes ruminants, humans, carnivores, reptiles, birds, and rodents [13]. The increased prominence of human infections, alternative treatment options, availability of whole genome data, and alternative/promising preventive measures are all important contributions, and could perhaps be stressed earlier. Therefore, it is imperative to mention the updated global epidemiological status, diagnosis, and control of canine anaplasmosis at the animal-human interface.

\section{History}

In 1910, Sir Arnold Theiler discovered bacteria of the Anaplasma genus. He was the first to observe these "marginal spots" in the red blood cells of South African cattle, which he called Anaplasma marginale [14]. He later described A. centrale as subspecies of $A$. marginale, which seems to be less pathogenic and localized more frequently in the center of red blood cells than in the margins of erythrocytes [14].

In 1932, Gordon and his colleagues first noticed a disease in sheep in Scotland without identifying the causative agent in louping ill-affected districts transmitted by Ixodes ricinus. Further investigation revealed pathogens in the blood, spleen, and central nervous system. Later, the disease was diagnosed as tick fever, and the clinico-pathological aspects of the disease were studied in detail [14-16].

In 1949, Foggie placed this pathogen in the Rickettsial group, since the disease is transmitted by ticks, and named it Ehrlichia phagocytophila ovis [17]. The designation Ehrlichiae was chosen in honor of the German microbiologist Paul Ehrlich [18]. In 1969, Gribble discovered, in California (U.S.), a bacterium of the Ehrlichia genus causing a fatal disease in horses. He called the disease "equine granulocytic ehrlichiosis" in reference to the location of the morulae in the granulocytes $[19,20]$. The bacterium was subsequently described and named Ehrlichia equi by Lewis and his colleagues in 1975 [20]. In 1994, Chen and his colleagues in the U.S. diagnosed clinical case of ehrlichiosis in a human patient; they named it human granulocytic ehrlichiosis (HGE) [7,21].

\section{Etiology}

The word Anaplasma is derived from the Greek words an and plasma; the former means "without" and the latter means "molded." Anaplasma, Ehrlichia, Wolbachia, and Neorickettsia belong to obligate intracellular bacteria that invade blood cells. Anaplasma is an obligate intracellular, Gram-negative alpha-proteobacteria that belongs to the Anaplasmataceae family, order Rickettsiales. Currently, A. marginale, A. bovis, A. ovis, A. platys, and A.phagocytophilum are important species of the genus Anaplasma (Table 1). 
Table 1. Classified and unclassified Anaplasma species infecting different cells, their vertebrate hosts, and their potential vectors.

\begin{tabular}{|c|c|c|c|c|}
\hline Anaplasma Species & Infecting Cells & Vertebrate Hosts & Potential Vectors & References \\
\hline A. platys & Platelets & Dogs and camels & Rhipicephalus & {$[22,23]$} \\
\hline A. phagocytophilum & Granulocytes & $\begin{array}{l}\text { Domestic and wild } \\
\text { ruminants, horses, } \\
\text { dogs, cats, rabbits, } \\
\text { rodents, insectivores, } \\
\text { wild swine, and } \\
\text { humans }\end{array}$ & $\begin{array}{c}\text { Ixodes, } \\
\text { Dermacentor, } \\
\text { Hyalomma, } \\
\text { Rhipicephalus }\end{array}$ & [13] \\
\hline A. marginale & Erythrocytes & Domestic ruminants & $\begin{array}{c}\text { Rhipicephalus, Ixodes, } \\
\text { Dermacentor }\end{array}$ & [24] \\
\hline A. centrale & Erythrocytes & $\begin{array}{l}\text { Domestic and wild } \\
\text { ruminants }\end{array}$ & $\begin{array}{c}\text { Rhipicephalus, Ixodes, } \\
\text { Haemaphysalis }\end{array}$ & [1] \\
\hline A. ovis & Erythrocytes & $\begin{array}{l}\text { Domestic and wild } \\
\text { ruminants and humans }\end{array}$ & $\begin{array}{c}\text { Rhipicephalus, } \\
\text { Dermacentor, } \\
\text { Hyalomma }\end{array}$ & [1] \\
\hline A. bovis & Monocytes & $\begin{array}{l}\text { Domestic and wild } \\
\text { ruminants and small } \\
\text { mammals }\end{array}$ & $\begin{array}{l}\text { Haemaphysalis, } \\
\text { Rhipicephalus, } \\
\text { Amblyomma }\end{array}$ & [25] \\
\hline A. capra & Erythrocytes & $\begin{array}{l}\text { Domestic and wild } \\
\text { ruminants and humans }\end{array}$ & Haemaphysalis & {$[26,27]$} \\
\hline A. odocoilei & Platelets & Wild ruminants & Not known & [28] \\
\hline Candidatus A. camelii & Not known & Camels & Not known & [29] \\
\hline Candidatus A. boleense & Not known & Not known & Hyalomma & [30] \\
\hline $\begin{array}{l}\text { Candidatus A. } \\
\text { corsicanum }\end{array}$ & Not known & Domestic ruminants & Not known & [31] \\
\hline $\begin{array}{l}\text { Candidatus A. } \\
\text { mediterraneum }\end{array}$ & Not known & Domestic ruminants & Not known & [31] \\
\hline Candidatus A. sphenisci & Not known & African penguins & Not known & [32] \\
\hline $\begin{array}{l}\text { Candidatus A. } \\
\text { rodmosense }\end{array}$ & Not known & Rodents & Not known & [33] \\
\hline
\end{tabular}

The sequencing of the whole genome of A. phagocytophilum was evaluated and shown to contain a 1.2-1.5 $\times 10^{6}$ bp circular chromosome [34]. Likewise, A. platys has a1.196 $\times 10^{6}$ bp genome size [35]. Anaplasma platys frequently infects dogs; however, it has also been reported in cats, camels, and humans. Nonetheless, A. ovis has also been described in humans [36]. Anaplasma spp. demonstrates some level of host specificity; this attribute is altered due to the detection of Anaplasma species in various hosts, which further complicates the pathology and epidemiology of the disease [36].

\section{Taxonomical Position of Anaplasma Bacteria}

\subsection{Evolution of Taxonomy}

The Anaplasmataceae family is included in the order Rickettsiales, obligate intracellular bacteria that exist in eukaryotic cells. Morphologically (Gram-negative bacteria) and epidemiologically, they have a particular tropism for blood cells, since all of them are mainly transmitted by ticks. This classification of Anaplasmataceae is based on the pathogenic characteristics of these bacteria, which are strictly intracellular [37]. Studies of Weisburg and Sumner and colleagues have revealed that, in reality, Ehrlichia phagocytophila and Ehrlichia equi are genetically similar to the etiologic agent of human granulocytic anaplasmosis $[38,39]$. Based on the sequencing and phylogenetic proximity of these bacterial operons/genes (groESL, gltA, ankA, and 16S ribosomal RNA), Dumler and his collaborators made profound taxonomic changes, leading to the reorganization of most family members, genera, and species of Rickettsiales [40]. 


\subsection{Current Classification}

Carrade and his collaborators reorganized the classification on the basis of their nucleic acid sequences, known antigenic properties, ecology, geographical distribution, and their pathogenicity. They mainly used the 16S rRNA gene and groESL operon, and divided this order into two families. One is Rickettsiaceae, which remains free in the cytoplasm, and the second is Anaplasmataceae, which is contained in a vacuole bound to the cytoplasmic membrane derived from the host cell [41]. The present classification is based on the phylogenetic analysis of the 16S rRNA and groESL genes replacing and renaming Ehrlichia (E.) bovis, E. platys, and E. phagocytophilum as A. bovis, A. platys, and A. phagocytophilum, respectively [40].

\section{Epidemiology}

Anaplasmosis has a worldwide distribution, and is potentially endemic in fortythree countries of the world [42]. Although, the prevalence varies among area, species, breeds, due to the presence of different ticks, and diagnostic assays involved. Anaplasma phagocytophilum and A. platys have been identified on all continents. Sufficient scientific data are available for $A$. phagocytophilum, while less epidemiological and risk factor information is available for $A$. platys. Nevertheless, A. phagocytophilum can infect a wide range of wild/domestic animals and humans; however, $A$. platys typically infects dogs and rarely cats $[13,43]$. Animals recover from acute anaplasmosis, develop a lifelong persistent infection with low cyclic rickettsiemia, and act as a reservoir host for further spread [44]. A. platys has zoonotic potential and there are reports of human infection to a lesser extent [45].

\subsection{Anaplasma platys}

Anaplasma platys was first observed in a blood test of a dog in the United States in 1978. It has been detected on almost all continents with worldwide distribution $[4,46-51]$. A. platys widely infects dogs; however, it has also been shown in deer, cats, cattle, and humans [5]. In dogs, severe thrombocytopenia results in recrudescence after two weeks of incomplete recovery. Thrombocytopenia can occur as a result of direct damage to platelets and immune cells caused by immune-mediated mechanisms [4]. In dogs and cats, the serological and molecular prevalence rates range from $0.4 \%$ to $87.5 \%$ and from $0.6 \%$ to $6.6 \%$, respectively, depending on the region, breed, and involved test (Table 2). Regarding the infected host, the overall prevalence and distribution of $A$. platys in domestic canids are shown in Table 2. Interestingly, the camel is an animal species that significantly harbors canine A. platys and various $A$. platys-like strains during natural infection [52-54]. It is necessary to determine the pathogenicity and the epidemiological role of camelids in the transmission of this Anaplasma species.

\subsection{Anaplasma phagocytophilum}

Anaplasma phagocytophilum is one of the most diverse pathogens infecting humans, and domestic and wild animals. This species is most widespread in northern Europe. Small mammals play a vital role in disease transmission. A. phagocytophilum is mainly transmitted by tick bites [55]. Disease outcome and response to treatment are complex in dogs, co-infected with H. canis, B. vogeli, and/or Ehrlichia canis. After the incidence of animal anaplasmosis in an area, the screening of human anaplasmosis should be considered. Sero-surveillance has shown a prevalence of $15-36 \%$ in humans with an annual incidence of approximately 58 cases per 100,000 individuals in the U.S. [18]. The rate of human infection increases with infected vectors. Indeed, there is a high rate of incidence of human granulocytic anaplasmosis (HGA) in the U.S. There were approximately 2782 cases of HGA recorded during the year 2013 [11].

Regarding HGA, patients' clinical signs range from asymptomatic to severe clinical disease, and approximately $40 \%$ of patients require hospitalization $[18,56,57]$. The mortality rate in the U.S. ranges from $7 \%$ to $10 \%$ [58-60]. The severity of infection depends on the 
phase of bacterial growth, the susceptibility of the host, and the pathogenic bacterial strain. A blood test of the infected host reveals that there is a decrease in the number of neutrophils and leukocytes, resulting in immunosuppression and a tendency of opportunistic infection [61]. Approximately30\% of the patients required prompt hospitalization due to the development of life-threatening conditions, including severe sepsis, anaphylactic shock, and respiratory syndrome [57]. Death occurs mainly due to a combination of other health problems, including intravascular coagulation, kidney failure, enlarged heart, coma, and seizures.

Table 2. Detection of A. platys in domestic canid hosts from different countries *

\begin{tabular}{|c|c|c|c|c|}
\hline Domestic Canid & Countries (Region) & Prevalences (\%) & Methods (Target Genes) & References \\
\hline \multirow[t]{46}{*}{ Dog } & Thailand & 13.9 & $\mathrm{PCR}^{\mathrm{a}}($ groEL $)$ & [62] \\
\hline & Thailand & 29.4 & $\mathrm{PCR}^{\mathrm{a}}(16 S \mathrm{r} R N A)$ & [63] \\
\hline & Thailand & 7.0 & $\mathrm{PCR}^{\mathrm{a}}\left(16 S\right.$ rRNA)/mHRM ${ }^{\mathrm{b}}$ & {$[64]$} \\
\hline & West Indies (Grenada) & 18.7 & $\mathrm{PCR}^{\mathrm{a}}(16 S \mathrm{r} R N A)$ & [65] \\
\hline & West Indies (Grenada) & 33.0 & $\mathrm{PCR}^{\mathrm{a}}(16 S \mathrm{rRNA}) / \mathrm{ELISA}^{\mathrm{c}}$ & {$[66]$} \\
\hline & West Indies (Grenada) & 16.4 & RT-PCR ${ }^{\mathrm{d}}(16 S r R N A)$ & [67] \\
\hline & West Indies (Trinidad) & 2.3 & $\mathrm{PCR}^{\mathrm{a}}(16 S r R N A) / \mathrm{RBL}^{\mathrm{e}}$ & [68] \\
\hline & Pakistan & 11.34 & $\mathrm{PCR}^{\mathrm{a}}(16 S r R N A)$ & [69] \\
\hline & Paraguay & 10.67 & $\mathrm{PCR}^{\mathrm{a}}(16 S \mathrm{r} R N A)$ & [70] \\
\hline & Colombia & 20.2 & $\mathrm{RT}^{-P_{C} \mathrm{~d}}(16 S r R N A)$ & [71] \\
\hline & Greece & Case report & Blood smear $/$ ELISA $^{c}$ & [72] \\
\hline & Indonesia & 11.76 & $\mathrm{PCR}^{\mathrm{a}}($ groEL $)$ & [73] \\
\hline & Cape Verde & 7.7 & $\mathrm{PCR}^{\mathrm{a}}(16 S \mathrm{r} R \mathrm{NA})$ & [74] \\
\hline & Italy & 70.5 & $\mathrm{PCR}^{\mathrm{a}}($ groEL) & [75] \\
\hline & Italy (Putignano) & 52.9 & RT-PCR ${ }^{\mathrm{C}}(16 S r R N A)$ & [76] \\
\hline & Italy (Teramo Kennel) & 33.0 & $\operatorname{PCR}^{\mathrm{a}}(16 S$ rRNA $) / \mathrm{RLB}^{\mathrm{e}}$ & [48] \\
\hline & Croatia & Case report & RT-PCR ${ }^{\mathrm{d}}(g r o E L)$ & [77] \\
\hline & Australia & 51.3 & RT-PCR ${ }^{\mathrm{d}}(16 S r R N A)$ & [78] \\
\hline & Australia & 23.7 & ELISA $^{c}$ & [78] \\
\hline & Australia & 32.0 & $\operatorname{PCR}^{\mathrm{a}}(16 S / 18 S$ rRNA) & [49] \\
\hline & Australia & 3.8 & Blood smear/ELISA ${ }^{\mathrm{c}} / \mathrm{PCR}^{\mathrm{a}}$ & [79] \\
\hline & Romania & Case report & $\mathrm{PCR}^{\mathrm{a}}(16 S \mathrm{r} R N A)$ & [80] \\
\hline & Dominican Republic & 11 & RT-PCR ${ }^{\mathrm{d}}(16 S / 18 S$ rRNA) & [81] \\
\hline & Nicaragua & 13 & RT-PCR ${ }^{\mathrm{d}}(16 S / 18 S$ rRNA) & [82] \\
\hline & Caribbean & 10.3 & ELISA $^{\mathrm{c}}$ & [83] \\
\hline & Canada & 1.8 & ELISA $^{\mathrm{c}}$ & [83] \\
\hline & USA (South) & 2.0 & ELISA $^{\mathrm{c}}$ & [83] \\
\hline & USA (Mid Atlantic) & 1.1 & ELISA $^{\mathrm{c}}$ & [83] \\
\hline & USA (Northeast) & 1.5 & ELISA $^{\mathrm{c}}$ & [83] \\
\hline & USA (Midwest) & 0.6 & ELISA $^{\mathrm{c}}$ & [83] \\
\hline & USA (West) & 1.0 & ELISA $^{c}$ & [83] \\
\hline & Mexico & 31.0 & $\operatorname{PCR}^{\mathrm{a}}(16 S$ rRNA) & [84] \\
\hline & Brazil & 7.19 & $\operatorname{PCR}^{\mathrm{a}}(16 S$ rRNA) & [51] \\
\hline & Turkey & 0.5 & RLB $^{\mathrm{d}}$ & [85] \\
\hline & Costa Rica & 1 & $\mathrm{PCR}^{\mathrm{a}}(16 S$ rRNA, groEL) & [86] \\
\hline & Brazil & 16.96 & $\mathrm{nPCR}^{\mathrm{f}}(16 S$ rRNA) & [87] \\
\hline & Brazil & 19.4 & $\mathrm{PCR}^{\mathrm{a}}(16 S \mathrm{rRNA})$ & [88] \\
\hline & Brazil & 14.07 & $\mathrm{nPCR}^{\mathrm{f}}(16 S r R N A) / \mathrm{ELISA}^{\mathrm{c}}$ & [89] \\
\hline & Colombia & 53.0 & $\mathrm{PCR}^{\mathrm{a}}(16 S \mathrm{rRNA}) /$ ELISA $^{\mathrm{c}}$ & [90] \\
\hline & Palestine & 53.0 & $\mathrm{PCR}^{\mathrm{a}}(16 S \mathrm{rRNA})$ & [91] \\
\hline & China & 62.1 & RT-LAMPg / nPCR ${ }^{\mathrm{f}}(16 S$ rRNA) & [92] \\
\hline & Caribbean & 18.7 & $\mathrm{PCR}^{\mathrm{a}}(16 S$ rRNA, glt $A$, groEl) & [65] \\
\hline & Argentina & 37.5 & $\mathrm{PCR}^{\mathrm{a}}(16 S$ rRNA, groESL) & [93] \\
\hline & Costa Rica & 6.25 & $\mathrm{nPCR}^{\mathrm{f}}(16 S r R N A) /$ ELISA $^{\mathrm{c}}$ & [94] \\
\hline & Myanmar & 0.25 & $\mathrm{PCR}^{\mathrm{a}}(16 S$ rRNA) & [95] \\
\hline & Malawi & 2.4 & $\mathrm{PCR}^{\mathrm{a}}(16 S \mathrm{rRNA})$ & [96] \\
\hline
\end{tabular}


Table 2. Cont.

\begin{tabular}{|c|c|c|c|c|}
\hline Domestic Canid & Countries (Region) & Prevalences (\%) & Methods (Target Genes) & References \\
\hline & Galápagos & 6.9 & $\mathrm{PCR}^{\mathrm{a}}(16 S r R N A) / \mathrm{ELISA}^{\mathrm{c}}$ & [97] \\
\hline & Saudi Arabia & 57.1 & RT-PCR ${ }^{\mathrm{C}}(16 S$ rRNA) & [98] \\
\hline & Greek islands & 18.0 & $\mathrm{PCR}^{\mathrm{a}}(16 S$ rRNA $) / \mathrm{IFAT}^{\mathrm{h}}$ & [99] \\
\hline & Malta & 22.7 & $\operatorname{PCR}^{\mathrm{a}}(16 S$ rRNA, $\operatorname{cox} 1)$ & [100] \\
\hline & Haiti & 6.3 & $\mathrm{PCR}^{\mathrm{a}}(16 S / 18 S \mathrm{rRNA})$ & [101] \\
\hline & Cambodia & 32.0 & NGSi based metabarcoding & [102] \\
\hline & Uganda & 18.9 & RT-PCR $^{\mathrm{d}}\left(16 S\right.$ rRNA)/IFAT ${ }^{\mathrm{h}}$ & [103] \\
\hline & Albania & 3.3 & $\mathrm{PCR}^{\mathrm{a}}\left(16 S\right.$ rRNA)/ELISA ${ }^{\mathrm{b}}$ & [104] \\
\hline & Nigeria & 6.6 & RT-PCR ${ }^{\mathrm{d}}(16 S$ rRNA) & [105] \\
\hline & Qatar & 1.6 & $\operatorname{PCR}^{\mathrm{a}}(16 S$ rRNA) & [106] \\
\hline & Texas & 0.17 & 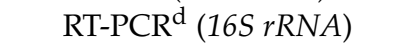 & [107] \\
\hline & India & 22.6 & $\mathrm{PCR}^{\mathrm{a}}(16 S$ rRNA) & [108] \\
\hline & Japan & 32.0 & $\mathrm{PCR}^{\mathrm{a}}(16 S \mathrm{rRNA})$ & [109] \\
\hline
\end{tabular}

${ }^{a}$ Polymerase chain reaction; ${ }^{b}$ multiplex high-resolution melting analysis; ${ }^{\mathrm{c}}$ enzyme-linked immunosorbent assay; ${ }^{\mathrm{d}}$ real-time polymerase chain reaction; ${ }^{\mathrm{e}}$ reverse line blot hybridization; ${ }^{\mathrm{f}}$ nested polymerization chain reaction; ${ }^{\mathrm{g}}$ real-time loop-mediated isothermal amplification;

$\mathrm{h}$ indirect fluorescent antibody test; ${ }^{\mathrm{i}}$ next-generation sequencing based on metabarcoding. ${ }^{*}$ Detection of A. platys from 1991 up to date.

The disease is more severe in elderly patients and immunocompromised children $[58,59]$.

Anaplasma phagocytophilum is mainly transmitted by ixodid ticks of the genera Ixodes, Dermacentor, Haemaphysalis, and Amblyomma in Europe, the U.S., and Asia [24]. In ticks, transstadial transmission occurs [110,111], while other routes of transmission are less common, such as contact with infected blood and tissues [57,112]. Serological and molecular prevalence rates vary from $0.3 \%$ to $55.6 \%$ for dogs and $0.9 \%$ to $37.6 \%$ for cats depending upon the area, breed, and test used (Table 3). The infected host, the global prevalence of infection, and the distribution of A. phagocytophilum in domestic canid hosts are listed in Table 3.

Table 3. Detection of A. phagocytophilum from the tissue or blood of domestic canids hosts *.

\begin{tabular}{|c|c|c|c|c|}
\hline Domestic Canid & Countries (Regions) & Prevalences (\%) & $\begin{array}{c}\text { Methods(Target } \\
\text { Genes) }\end{array}$ & References \\
\hline \multirow[t]{17}{*}{ Dog } & Iraq & 55.6 & Blood smear & [113] \\
\hline & Iran & 2.0 & $\mathrm{PCR}^{\mathrm{a}}(m s p 4)$ & [114] \\
\hline & Mexico & 27 & PCR $^{\mathrm{a}}$ (16S rRNA) & [115] \\
\hline & USA (California) & 7.6 & RT-PCR ${ }^{\mathrm{b}}(m s p 2)$ & [116] \\
\hline & Brazil & 7.1 & RT-PCR ${ }^{\mathrm{b}}(m s p 2)$ & [117] \\
\hline & USA (South) & 2.1 & ELISA $^{\mathrm{c}}$ & [83] \\
\hline & USA (Mid-Atlantic) & 5.4 & ELISA $^{\mathrm{c}}$ & [83] \\
\hline & USA (Northeast) & 13 & ELISA $^{\mathrm{c}}$ & [83] \\
\hline & USA (Midwest) & 1.9 & ELISA $^{\mathrm{c}}$ & [83] \\
\hline & USA (West) & 2.0 & ELISA $^{c}$ & [83] \\
\hline & Canada & 1.1 & ELISA $^{\mathrm{c}}$ & [83] \\
\hline & Caribbean & 3.4 & ELISA $^{\mathrm{c}}$ & [83] \\
\hline & Sweden & 17.0 & IFAT $^{d}$ & [118] \\
\hline & Colombia & 1.1 & $\mathrm{PCR}^{\mathrm{a}}$ (16S rRNA) & [119] \\
\hline & Costa Rica & 0.3 & $\mathrm{PCR}^{\mathrm{a}}$ (16SrRNA, groEL) & [86] \\
\hline & India & 0.4 & $\mathrm{PCR}^{\mathrm{a}}(16 \mathrm{~S} / 18 \mathrm{~S}$ rRNA) & [108] \\
\hline & Turkey & 4.0 & $\mathrm{nPCR}^{\mathrm{e}}(16 \mathrm{~S}$ rRNA) & [120] \\
\hline
\end{tabular}

${ }^{a}$ Polymerase chain reaction; ${ }^{b}$ real-time polymerase chain reaction; ${ }^{c}$ enzyme-linked immunosorbent assay; ${ }^{d}$ indirect fluorescent antibody test; ${ }^{\mathrm{e}}$ nested polymerization chain reaction. ${ }^{*}$ Detection of A. phagocytophilum from 1998 up to date.

\section{Transmission}

Ixodidae ticks act as biological vectors and play an essential role in the spread and propagation of Anaplasma during various stages of its life cycle [121]. Nonetheless, vertical transmission has also been reported for A. platys infection in bitches during early gestation 
(25-35 days) and intrauterine transmission for A. phagocytophilum as well [122-124]. Vertebrates are definitive hosts and also serve as reservoirs [125]. Rhipicephalus $(R$.$) sanguineus$ and I. ricinus are the major vectors of $A$. platys and A. phagocytophilum, respectively $[124,126]$.

\section{Life Cycle}

The life cycle of all Anaplasma species hasnot yet been completely studied. Most studies have been performed on $A$. marginale in cattle in association with $R$. microplusticks. The life cycle begins with the ingestion of Anaplasma by tick vectors during a blood meal [127]. A. phagocytophilum frequently infects granulocytes, causing leukopenia and thrombocytopenia. This changes the host's immune system and positively regulates cellular cholesterol and several tick genes.

However, A. platys primarily infects platelets causing thrombocytopenia, and can also infect megakaryocytes and promegakaryocytes [127]. Transstadial, transovarial, and mechanical propagation, as well as several other host-related factors, make the conditions essential for the maintenance of Anaplasma in nature [128].

\section{Clinical Findings}

In dogs, $A$. platys causes canine cyclic thrombocytopenia with variable signs of fever, anorexia, weakness, anemia, lethargy, eye discharge, spot hemorrhage on the eye, oral mucosa and skin, respiratory distress, lymphadenomegaly, epistaxis, splenomegaly, and muzzle hyperkeratosis $[46,129,130]$. Thrombocytopenia may occur as a result of direct damage to platelets by the pathogen and immune-mediated systems [4]. Camels infected with $A$. platys generally remain asymptomatic, with some evidence of anorexia, dullness, progressive loss of physical condition, and stamina, as well as neutrophilia and eosinophilia [22]. Canine granulocytic anaplasmosis shows signs of high fever, vomiting, diarrhea, loss of appetite, lameness, polyuria, jaundice, epistaxis, lymphatic adenomegaly, and splenomegaly [131,132]. Cats show no specific clinical signs; however, signs of anorexia, fever, lethargy, and dryness with neutrophilia, lymphopenia, thrombocytopenia, and hyperglycemia can be observed [133-135].

In humans, A. phagocytophilum causes human granulocytic anaplasmosis. Patients present with flu-like symptoms ranging from asymptomatic to severe clinical illnesses. High fever, severe headache, stiff neck, myodynia, restlessness, cough, nausea, and vomiting are important clinical signs, and even diarrhea, joint pain, and neurological signs [136,137]. During illness, certain threatening conditions can develop in patients due to opportunistic pathogens. Often, laboratory tests are needed to maintain the diagnosis. Approximately $30 \%$ of the patients require hospitalization due to anaphylactic shock, severe sepsis, and respiratory syndrome [57]. The disease mortality rate is $7-10 \%$ in the United States $[58,60]$. Death occurs mainly due to the combination of other health problems related to intravascular coagulation, kidney failure, enlarged heart, coma, and seizures. The disease is more harmful in elderly immunocompromised patients [112].

\section{Diagnosis}

Diverse conventional, serological, and molecular methods have been validated for causative agent identification and disease diagnosis.

\subsection{Direct Detection}

Conventional light microscopy of freshly prepared stained blood smears (Giemsa, Diff-Quik) taken from a vein are used for diagnosis in the acute phase of the disease (Figures 1-3). A. phagocytophilum leads to the development of "morulae," which are a combination of mulberry-type colonies formed in the neutrophils and eosinophils of infected organisms [61]. 


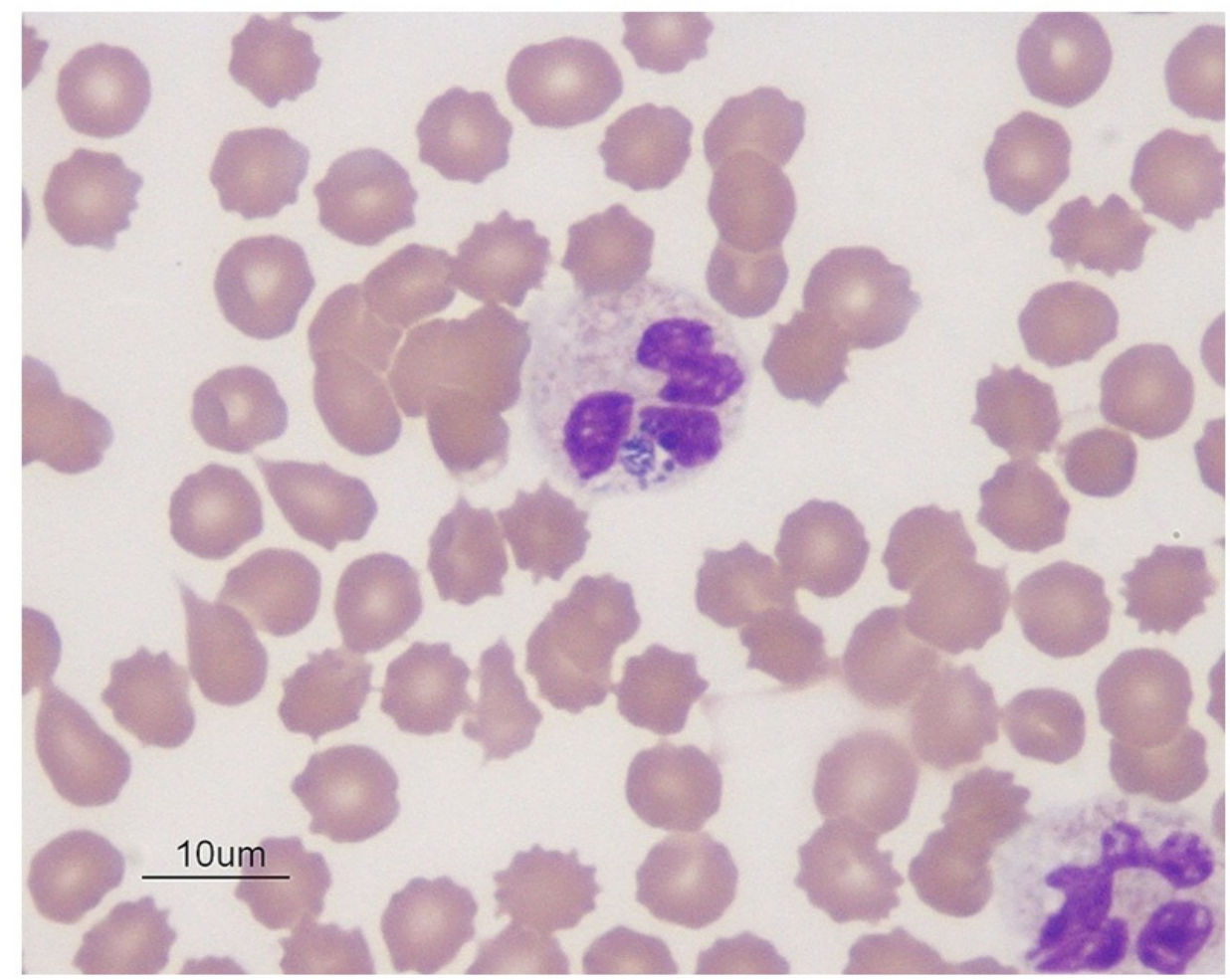

Figure 1. Blue color Anaplasma phagocytophilum in the cytoplasm of neutrophils in dog blood; Wright's stain, $1000 \times$ (source: https:/ / eclinpath.com; accessed on 11 August 2021; Cornell University College of Veterinary Medicine).

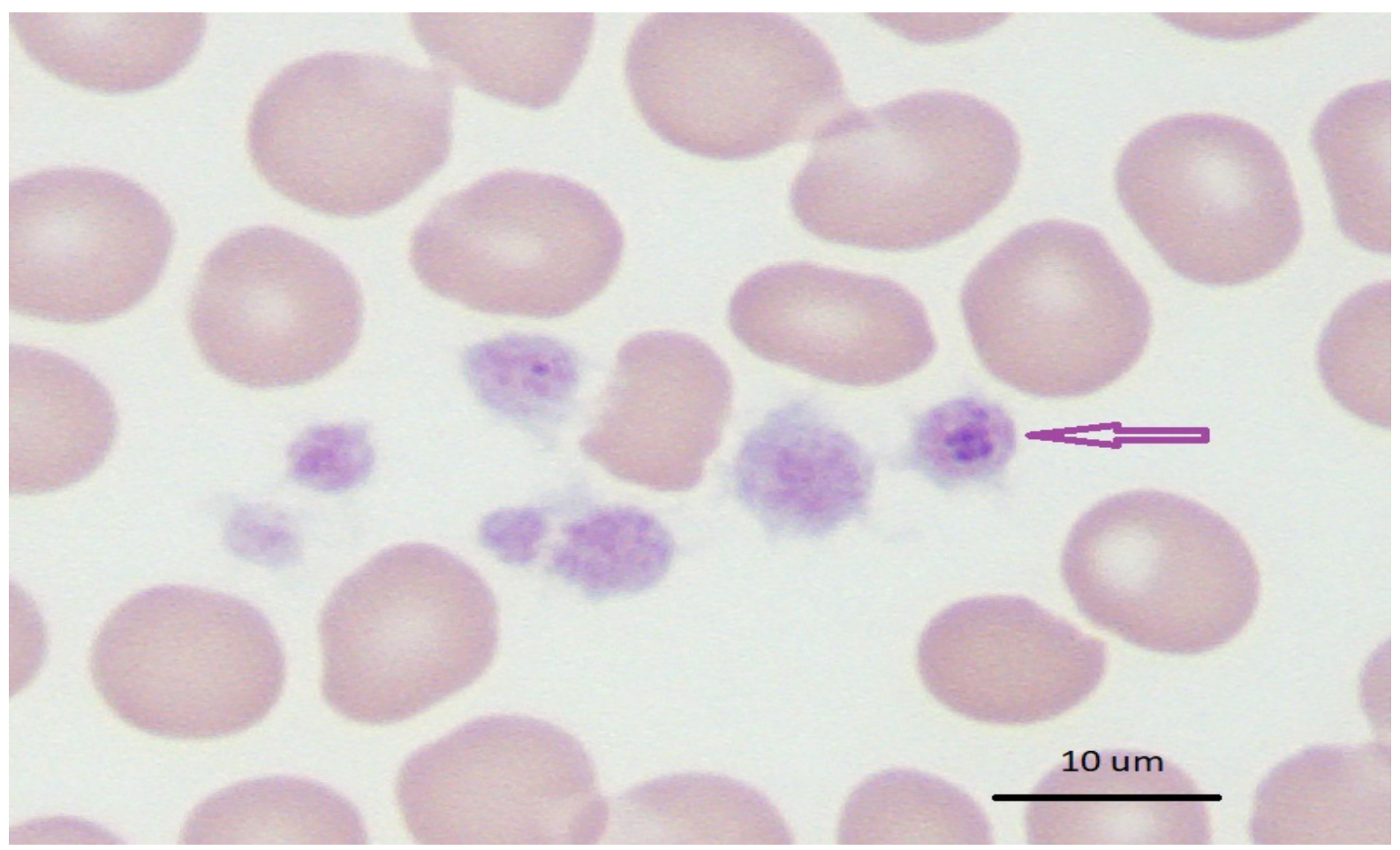

Figure 2. Blue-purple inclusions of Anaplasma platys in dog blood with thrombocytopenia; Wright's stain $1000 \times($ source: https:/ / eclinpath.com; accessed on 11 August 2021; Cornell University College of Veterinary Medicine).

Typically, Anaplasma morulae resembledark blue to purple inclusion bodies. Conversely, refrigerated samples mixed with anticoagulants can be processed within $24-48 \mathrm{~h}$. 
This is a quick, inexpensive, and best way to directly visualize bacteria before the start of antibacterial treatment. However, this method is less sensitive to lower bacteremia during persistent infection with monocytopenia, neutropenia, thrombocytopenia, and anemia $[138,139]$. The sample collection time is critical for the direct identification of bacteria involving microscopy, in vitro culture, and nucleic acid detection in order to detect sufficient number of organisms in the circulating blood [140]. Leukocyte smears would be a good option for A. platys and A. phagocytophilum morulae compared to whole blood. As these organisms are limited to platelets and leukocytes, this enriched fraction is cogently useful for the identification of cases of leucopenia and thrombocytopenia encountered as clinical sequelae [140].

For specific research, scanning electron microscopy, confocal microscopy, and transmission electron microscopy can be useful for the detection of these bacteria in ticks, mites, lice, and other invertebrates. Smears of tissue impressions from the liver, spleen, heart, lungs, kidneys, and/or blood vessels can be used during necropsy, especially for wild animal species $[139,141]$.

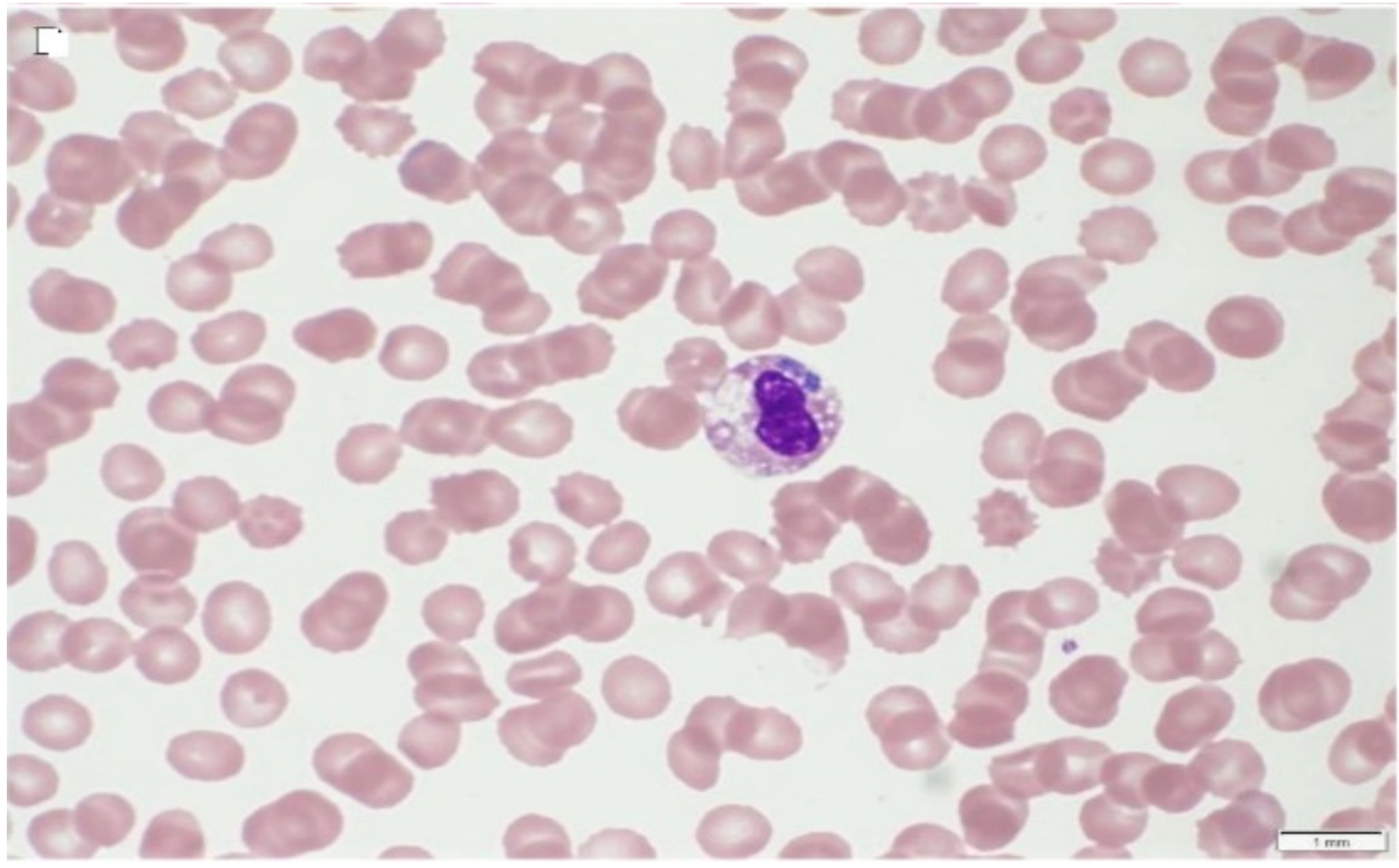

Figure 3. Human A. phagocytophilum infection, indicating morulae in infected neutrophils [142].

\subsection{Serology}

Some companies provide commercial diagnostic kits for the serodiagnosis of anaplasmosis in animals and humans with variable accuracy. The IgG and IgM antibodies for A. phagocytophilum can be detected using a commercial kit based on IFAT "Fuller Laboratories" [143]. In addition, "SNAP 4Dx Plus," a commercial test, allows for the detection of antibodies to A. platys and A. phagocytophilum, as well as other canine pathogens (Ehrlichia canis or Ehrlichia ewingii, Borrelia burgdorferi, and Dirofilaria immitis).

Likewise, the "Canine Anaplasma Antibody Test Kit" of VetScan ${ }^{\circledR}$ (Abaxis) provides a rapid test thatqualitatively detects $A$. platys and/or A. phagocytophilum antibodies in dog serum or plasma. Similarly, "Anti-Anaplasma phagocytophilum ELISA Dog (IgG)" from EUROIMMUN (Medizinische Labordiagnostika AG) identifies seropositivity to A. phagocytophilum in dogs. Furthermore, the "Rapid Anaplasma Ab Test Kit" from the BIONOTE 
company is a commercial immunological test kit thatallows the qualitative chromatographic detection of the antibodies of A. phagocytophilum and A. platys.

Nevertheless, "MegaCorDiagnostik" performs immunochromatographic testing based on the lateral flow method, and "FASTest Anaplasma" provides qualitative discovery of Anaplasma phagocytophilum antibodies in dog and horse serum/plasma, which are commercially available for the convenient screening of anaplasmosis.

\subsection{Molecular Detection}

Nucleic acid detection methods, including conventional, nested and semi-nested PCR, real-time PCR, and LAMP (loop-mediated isothermal amplification), have been used for diagnosis. The $16 S r R N A$, citrate synthase, heat shock, and major surface proteins (Msp1, Msp2, Msp4, and Msp5) are the most targeted genes for the molecular diagnosis of anaplasmosis [144].

Various high-performance single molecular and multiplex detection techniques with automation potential are in vogue. Whole blood containing ethylenediaminetetraacetic acid/citrate and buffy coat are good samples for diagnosis, while spleen samples are offered for the detection of carrier animals, especially in cases of wild animals $[140,145,146]$. Other types of samples, including the plasma/serum, lungs, liver, lymph nodes, skin, and bone marrow, have been used for screening [140,147-149]. For molecular diagnosis, multi copy genes are preferred over single copy genes. There is a growing trend to use fast and sensitive real-time assays over nested PCRs. Nonetheless, real-time screening assays yield short DNA products of less than $150 \mathrm{bp}$, yielding limited phylogenetical data. Sequencing and cross-matching are generally required for confirmation.

Different LAMP protocols have been developed for the identification of several Anaplasma species targeting the msp1b, gltA, 16S rRNA, and msp5 genes with variable detection limits. LAMP has the advantage of being a simple, robust, inexpensive, rapid, highly sensitive, and explicit diagnostic tool with low heat requirements, as well as options to use numerous primers [150]. For example, Lee and coworkers developed LAMP for the detection of $A$. phagocytophilum in dogs using the glt $A$ gene, and this method was found to be more sensitive than nested PCR [151]. Likewise, $\mathrm{Li}$ and his colleagues developed a real-time LAMP for A. platys in dogs using citrate synthase gene sequences at $63{ }^{\circ} \mathrm{C}$ for $30 \mathrm{~min}$. Uniform results and no cross-reactivity with other Anaplasma/Ehrlichia species were observed compared to nested PCR results [152].

Real-time molecular diagnostic methods have been developed for direct detection in blood, tissue, ticks/vectors that target multiple genes, which can be further used for taxonomic and phylogenetic studies. Whole genome sequencing of $A$. phagocytophilum and A. platys has been completed $[34,35,153]$. This will further contribute to the development of vaccines and diagnostic and control approaches for these important bacteria.

\subsection{Isolation and In Vitro Cultivation}

Isolation and in vitro culture are crucial, as all emerging bacteria have been grown on artificial media or cell lines. Indeed, ethical implications for animal use have led researchers to adapt the isolation and propagation of Anaplasma in cell culture lines derived from mammals on an uninterrupted basis. The HL-60 and THP- 1 cells have been widely used $[154,155]$. Tick cell lines are alternative options for the in vitro cultivation of Anaplasma species [156]. Fresh infected blood from animals or humans is the best inoculum for in vitro propagation. For example, the cell line derived from embryos of Ixodes scapularis (IDE8, ISE6), R. appendiculatus (RAE25), Dermacentor variabilis (DVE1), as well as the cell lines I. ricinus IRE/CTVM19, IRE11, L610, and IRE/CTVM20, have been used for the culture and isolation of A. phagocytophilum [144,157]. Cells derived from I. scapularis (ISE6) are also used for culturing new isolates of $A$. platys-like bacteria [28]. 


\section{Control}

Usually, the control of anaplasmosis is difficult due to the existing antigenic/genetic diversity, the involvement of several hosts and multiple arthropod vectors, as well as different transmission potentials (biological, mechanical, and transplacental) [1]. In general, control measures include the control of arthropod vectors, host resistance and vaccination, sanitary/hygienic measures, and rarely chemoprophylaxis. However, the deterrence of tick infestation during periods of active transmission appears to be the best policy for the control of animal and human anaplasmosis [1].

\subsection{Vector Control}

Prevention strategies for common tick-borne diseases of domestic animals are based on the reduction of tick infestation using chemical acaricides [2]. Acaricidal treatment should be applied especially during the tick season. Biological tick control is gaining in importance as a striking approach to take, but it is generally difficult to achieve, since ticks have few natural enemies. Therefore, studies have focused on bacteria, entomopathogenic nematodes, and fungi $[158,159]$. However, the major concern is to establish sustainable biological control of ticks in natural habitats.

Tick vaccines are alternative control options against acaricides. The vaccination of animal-human populations at risk and/or the reservoir are important for limiting the distribution of tick-borne pathogens $[160,161]$. The development of combined vaccines targeting both pathogens transmitted by ticks and ticks themselves would be beneficial at large. There are various candidate proteins for a tick vaccine such as Bm86, Ba86, 64P, and RmAQP1. In addition, the salivary proteins Salp16 and Sialo L2 from I. scapularis protect the transmission of $A$. phagocytophilum infection [162].

Similarly, I. ricinus heme lipoprotein and uncharacterized secreted protein, as well asfive of the secreted proteins of D. reticulatus (glypican-like), which are involved in anion or sulfate exchangers, homophilic cell adhesion, subunit 3 of the signal peptidase complex, and other secreted proteins have been identified as the most effective vaccine candidates [163].

Subolesin is a protein that plays a role in reproduction, blood digestion, and development of ticks [164]. These types of vaccines cause disintegration of reproductive and embryonic tissues, causing sterility in male ticks, as well as degeneration of tick guts and salivary glands [165]. Tick vaccines are possible, cost-effective, and environmentally friendly methods compared to chemical control [44].

\subsection{Vaccination against $A$. phagocytophilum and A. platys}

Vaccination is the most effective and cheapest defense against anaplasmosis. It should be mentioned that the complete genome sequence of $A$. phagocytophilum and $A$. platys has been accomplished $[34,35,153]$. This can help to explore many new genes that could be potential candidates for vaccine manufacturing. There are approximately nine Anaplasma proteins that have immunogenic potential, namely, the Asp14, Asp55, Msp5, Msp2, AipA, OmpA, APH 0032, and APH 1384 antigens of the type IV secretion system of A. phagocytophilum [153,166-169].

\subsection{Chemotherapeutic Use}

Anaplasma bacteria are sensitive to antibiotics from the tetracycline group. Doxycycline is effective against human granulocytic anaplasmosis [11]. Similarly, doxycycline is also a useful chemotherapeutic agent for $A$. platys infection in dogs at a dose rate of $10 \mathrm{mg} / \mathrm{kg}$ body weight orally with or without dexamethasone $(0.3 \mathrm{mg} / \mathrm{kg}$ IM daily) for 28 days [148]. In a situation of severe anemia, a blood transfusion is necessary.

Likewise, A. phagocytophilum infection in dogs can be treated with orbifloxacin at $5 \mathrm{mg} / \mathrm{kg}$ SC on day 1 and then orally on day 2 SID for two weeks. Other options that have proven effective for $A$. phagocytophilum infection in dogs include enrofloxacine $(5 \mathrm{mg} / \mathrm{kg}$ SC, SID) and prednisolone (SID $1.5 \mathrm{mg} / \mathrm{kg} \mathrm{SC}$ ) on day 1, and orbifloxacin ( $4 \mathrm{mg} / \mathrm{kg} \mathrm{SC}$ ) and 
prednisolone (1 mg/kg SC) from days 2-8 [170]. Animals with severe anemia accompanied by debility should be hospitalized.

Concomitant infection with A. platys and/or A. phagocytophilum in dogs, as well as with E. canis, Babesia vogeli, Borrelia burgdorferi, Hepatozoon canis and/or Leishmania infantum, has been reported $[5,171]$. Concurrent infections may obscure epidemiology, alter treatment, and present an atypical clinical picture. The clinical veterinarian should keep this aspect of coinfection in mind when dealing with anaplasmosis cases in the clinic. A summary of the treatment protocols is presented in Table 4 .

Table 4. Summary of the clinical findings, diagnosis, and control of canine cyclic thrombocytopenia, and canine and human granulocytic anaplasmosis.

\begin{tabular}{|c|c|c|c|c|}
\hline Disease & Clinical Findings & Diagnosis & Treatment & Control \\
\hline $\begin{array}{l}\text { Canine cyclic } \\
\text { thrombocytopenia }\end{array}$ & $\begin{array}{c}\text { Dogs usually remain } \\
\text { asymptomatic; } \\
\text { however, fever, } \\
\text { lethargy, anorexia, } \\
\text { weight loss, anemia, } \\
\text { icterus, petechiae, nasal } \\
\text { discharge, } \\
\text { lymphadenopathy, and } \\
\text { lymphadenomegaly } \\
\text { may beobserved [5] }\end{array}$ & $\begin{array}{l}\text { Stained blood smear, } \\
\text { thrombocytopenia, } \\
\text { serology, and } \\
\text { PCR/DNA } \\
\text { sequencing [5] }\end{array}$ & $\begin{array}{c}\text { Doxycycline } \\
@ 5-10 \mathrm{mg} \mathrm{kg}^{-1} \\
\text { q12-24 } \mathrm{h} \text { for } 8-10 \text { days } \\
\text { orenrofloxacin @ } \\
5 \mathrm{mg} \mathrm{kg}^{-1}, \mathrm{q} 12 \mathrm{~h} \text { for } \\
14-21 \text { days [5] }\end{array}$ & $\begin{array}{l}\text { Tick elimination, collar, } \\
\text { pour-on or spot-on } \\
\text { acaricidal products for } \\
\text { R. sanguineus sensu lato } \\
\text { ticks, knowledge of tick } \\
\text { seasonality, } \\
\text { andecology [5] }\end{array}$ \\
\hline $\begin{array}{l}\text { Canine granulocytic } \\
\text { anaplasmosis }\end{array}$ & $\begin{array}{c}\text { Non-specific signs, } \\
\text { fever, anemia, anorexia, } \\
\text { dullness, and } \\
\text { thrombocytopenia [5] }\end{array}$ & $\begin{array}{c}\text { Morulae in stained } \\
\text { blood smear, } \\
\text { thrombocytopenia, } \\
\text { leucopenia, elevated } \\
\text { liver enzymes, serology, } \\
\text { andPCR/DNA } \\
\text { sequencing }[1,5]\end{array}$ & $\begin{array}{c}\text { Doxycycline } 5 \mathrm{mg} / \mathrm{kg} \\
\text { bid for } 28 \text { days [172] }\end{array}$ & $\begin{array}{l}\text { Vector control, habitat } \\
\text { modification, rearing } \\
\text { tick-resistant breeds, } \\
\text { and chemotherapy [5] }\end{array}$ \\
\hline $\begin{array}{l}\text { Human granulocyti- } \\
\text { canaplasmosis }\end{array}$ & $\begin{array}{l}\text { Fever, headache, } \\
\text { myalgias, and } \\
\text { chills [123] }\end{array}$ & $\begin{array}{c}\text { Morulae in stained } \\
\text { blood smear, } \\
\text { thrombocytopenia, } \\
\text { leucopenia, elevated } \\
\text { liver enzymes, } \\
\text { serology/IFA, and } \\
\text { PCR/DNA } \\
\text { sequencing }[95,173]\end{array}$ & $\begin{array}{c}\text { Doxycycline @ } 100 \mathrm{mg}, \\
\text { orally, twice dailyfor } \\
10-14 \text { days or } \\
\text { rifampicin @ } \\
20 \mathrm{mgkg}^{-1} \text { day }^{-1} \\
\text { orallyfor children, } \\
\text { otherwise } 300 \mathrm{mg} \\
\text { orally, twice dailyfor } \\
5-7 \text { days [47] }\end{array}$ & $\begin{array}{l}\text { Humans: Minimizing } \\
\text { high-risk tick exposure } \\
\text { activities } \\
\text { (hiking, gardening, } \\
\text { etc.), blood transfusion, } \\
\text { immune suppression, } \\
\text { identificationof } \\
\text { reservoirs and vectors, } \\
\text { and their control [1] }\end{array}$ \\
\hline
\end{tabular}

\section{Conclusions}

Concretely, the adoption of control strategies varies according to geo-ecological circumstances. Integrated control of major reservoirs/vectors/ticks and hygienic sanitary measures are key elements in reducing disease transmission. As there is greater risk of mortality in older animals than younger ones, thus these individuals/animals should be treated as a priority. Doxycycline with or without dexamethasone is a significant treatment for human and animal anaplasmosis. However, reducing high-risk tick contact activities in humans (such as gardening and hiking), careful blood transfusion, circumventing immunosuppression, recognizing reservoirs/vectors, and control ofvectorsare significant defense strategies against human anaplasmosis.

Author Contributions: Conceptualization, F.A.A., S.M., M.F.Q., M.S.S., S.E.-u.-H., M.B.S., T.R., M.K.; Writing—original draft preparation, F.A.A., M.B.S.; Writing—review and editing, M.F.Q., M.B.S.; Visualization, S.E.-u.-H., T.R., M.S.S.; Funding acquisition, F.A.A.; Project administration, F.A.A., S.M., M.K. All authors have read and agreed to the published version of the manuscript. 
Funding: This review paper was supported by the Pakistan Science Foundation, project no. PSF/NSLP/PUVAS (697), and the Higher Education Commission of Pakistan, NRPU project no. 9041, as well as by the research projects "Screening and molecular characterization of pathogenic and zoonotic bacteria of medical and economic interest in cattle and camel ticks in Tunisia" (19PEJC07-22) and "Study of the bacterial microbiota in ticks with a medical and economic impact in Tunisia: contribution to the control of vector-borne bacterial diseases" (P2ES2020-D4P1), funded by the Ministry of Higher Education and Scientific Research of Tunisia.

Institutional Review Board Statement: Not applicable.

Informed Consent Statement: Not applicable.

Data Availability Statement: The study did not report any data.

Conflicts of Interest: The authors declare that the research was conducted in the absence of any commercial or financial relationships that could be construed as a potential conflict of interest.

\section{References}

1. Atif, F.A. Alpha proteobacteria of genus Anaplasma (Rickettsiales: Anaplasmataceae): Epidemiology and characteristics of Anaplasma species related to veterinary and public health importance. Parasitology 2016, 143, 659-685. [CrossRef] [PubMed]

2. Ben Said, M.; Belkahia, H.; Messadi, L. Anaplasma spp. in North Africa: A review on molecular epidemiology, associated risk factors and genetic characteristics. Ticks Tick Borne Dis. 2018, 9, 543-555. [CrossRef]

3. Stiller, D.; Crosbie, P.R.; Boyce, W.M.; Goff, W.L. Dermacentor hunteri (Acari: Ixodidae): An experimental vector of Anaplasma marginale and A. ovis (Rickettsiales: Anaplasmataceae) to calves and sheep. J. Med. Entomol. 1999, 36, 321-324. [CrossRef]

4. Harvey, J.W.; Simpson, C.F.; Gaskin, J.M. Cyclic thrombocytopenia induced by a Rickettsia-like agent in dogs. J. Infect. Dis. 1978, 137, 182-188. [CrossRef]

5. Sainz, A.; Roura, X.; Miro, G.; Estrada-Pena, A.; Kohn, B.; Harrus, S.; Solano-Gallego, L. Guideline for veterinary practitioners on canine ehrlichiosis and anaplasmosis in Europe. Parasit. Vectors 2015, 8, 2-9. [CrossRef] [PubMed]

6. Battilani, M.; De Arcangeli, S.; Balboni, A.; Dondi, F. Genetic diversity and molecular epidemiology of Anaplasma. Infect. Genet. Evol. 2017, 49, 195-211. [CrossRef] [PubMed]

7. Chen, S.M.; Dumler, J.S.; Bakken, J.S.; Walker, D.H. Identification of a granulocytotropic Ehrlichia species as the etiologic agent of human disease. J. Clin. Microbiol. 1994, 32, 589-595. [CrossRef] [PubMed]

8. Arraga-Alvarado, C.; Palmar, M.; Parra, O.; Salas, P. Fine structural characterisation of a Rickettsia-like organism in human platelets from patients with symptoms of ehrlichiosis. J. Med. Microbiol. 1999, 48, 991-997. [CrossRef] [PubMed]

9. Maggi, R.G.; Mascarelli, P.E.; Havenga, L.N.; Naidoo, V.; Breitschwerdt, E.B. Co-infection with Anaplasma platys, Bartonella henselae and Candidatus Mycoplasma haematoparvum in a veterinarian. Parasit. Vectors 2013, 6, 1-10. [CrossRef]

10. Breitschwerdt, E.B.; Hegarty, B.C.; Qurollo, B.A.; Saito, T.B.; Maggi, R.G.; Blanton, L.S.; Bouyer, D.H. Intravascular persistence of Anaplasma platys, Ehrlichia chaffeensis, and Ehrlichia ewingii DNA in the blood of a dog and two family members. Parasit. Vectors 2014, 7, 1-7. [CrossRef] [PubMed]

11. CDC. Centers for Disease Control and Prevention, National Center for Emerging and Zoonotic Infectious Diseases (NCEZID), Division of Vector-Borne Diseases (DVBD). Available online: https://www.cdc.gov/anaplasmosis/stats/index.html (assessed on 23 April 2019).

12. Reppert, E.; Galindo, R.C.; Breshears, M.A.; Kocan, K.M.; Blouin, E.F.; de la Fuente, J. Demonstration of transplacental transmission of a human isolate of Anaplasma phagocytophilum in an experimentally infected sheep. Transbound. Emerg. Dis. 2013, 60, 93-96. [CrossRef] [PubMed]

13. Stuen, S.; Granquist, E.G.; Silaghi, C. Anaplasma phagocytophilum-a widespread multi-host pathogen with highly adaptive strategies. Front. Cell. Infect. Microbiol. 2013, 3, 31. [CrossRef] [PubMed]

14. Gordon, W.S.; Brownlee, A.; Wilson, D.R.; MacLeod, J. Tick-Borne Fever (A hitherto undescribed disease of sheep). J. Comp. Path. 1932, 45, 106. [CrossRef]

15. MacLeod, J.; Gordon, W.S. Studies on tick borne fever in sheep I. Transmission by the tick Ixodes ricinus and description of the disease produced. Parasitology 1933, 25, 273-283. [CrossRef]

16. MacLeod, J. Studies on tick-borne fever of sheep. 2. Experiment on transmission and distribution of the disease. Parasitology. 1936, 28, 320-329. [CrossRef]

17. Foggie, A. Studies on tick-borne fever in sheep. J. Gen. Microbiol. 1949, 3, 5-6.

18. Dumler, J.; Choi, K.; Garcia, J.; Barat, N.; Scorpio, D.; Garyu, J.; Grab, D.; Bakken, J. Human Granulocytic Anaplasmosis and Anaplasma phagocytophilum. Emerg. Infect. Dis. 2005, 11, 1828-1839. [CrossRef] [PubMed]

19. Gribble, D.H. Equine ehrlichiosis. J. Am. Vet. Med. Assoc. 1969, 155, 462-469. [PubMed]

20. Lewis, J.E.; Huxsoll, D.L.; Ristic, M.; Johnson, A.J. Experimentally induced infection of dogs, cats, and nonhuman primates with Ehrlichia equi, etiologic agent of equine ehrlichiosis. Am. J. Vet. Res. 1975, 36, 85-88.

21. Bjöersdorff, A.; Bagert, B.; Massung, R.F.; Gusa, A.; Eliasson, I. Isolation and characterization of two European strains of Ehrlichia phagocytophila of equine origin. Clin. Diagn. Lab. Immunol. 2002, 9, 341-343. [CrossRef] 
22. Li, H.; Zheng, Y.; Ma, L.; Jia, N.; Jiang, B.; Jiang, R.; Huo, Q.; Wang, Y.; Liu, H.; Chu, Y.L.; et al. Human infection with a novel tick-borne Anaplasma species in China: A surveillance study. Lancet Infect. Dis. 2015, 15, 663-670. [CrossRef]

23. Chandra, S.; Smith, K.; Alanazi, A.D.; Alyousif, M.S.; Emery, D.; Šlapeta, J. Rhipicephalus sanguineus sensu lato from dogs and dromedary camels in Riyadh, Saudi Arabia: Low prevalence of vector-borne pathogens in dogs detected using multiplexed tandem PCR panel. Folia Parasitol. 2019, 66, 1-13. [CrossRef] [PubMed]

24. Atif, F.A. Anaplasma marginale and Anaplasma phagocytophilum: Rickettsiales pathogens of veterinary and public health significance. Parasitol. Res. 2015, 114, 3941-3957. [CrossRef] [PubMed]

25. Kawahara, M.; Rikihisa, Y.; Lin, Q.; Isogai, E.; Tahara, K.; Itagaki, A.; Hiramitsu, Y.; Tajima, T. Novel genetic variants of Anaplasma phagocytophilum, Anaplasma bovis, Anaplasma centrale, and a novel Ehrlichia sp. in wild deer and ticks on two major islands in Japan. Appl. Environ. Microbiol. 2006, 72, 1102-1109. [CrossRef] [PubMed]

26. Yang, J.; Liu, Z.; Niu, Q.; Liu, J.; Han, R.; Liu, G.; Shi, Y.; Luo, J.; Yin, H. Molecular survey and characterization of a novel Anaplasma species closely related to Anaplasma capra in ticks, northwestern China. Parasit. Vectors 2016, 9, 603-605. [CrossRef] [PubMed]

27. Peng, Y.; Lu, C.; Yan, Y.; Shi, K.; Chen, Q.; Zhao, C.; Wang, R.; Zhang, L.; Jian, F.; Ning, C. The first detection of Anaplasma capra, an emerging zoonotic Anaplasma sp., in erythrocytes. Emerg. Microbes. Infect. 2021, 10, 1-19. [CrossRef] [PubMed]

28. Tate, C.M.; Howerth, E.W.; Mead, D.G.; Dugan, V.G.; Luttrell, M.P.; Sahora, A.I.; Munderloh, U.G.; Davidson, W.R.; Yabsley, M.J. Anaplasma odocoilei sp. nov. (family Anaplasmataceae) from white-tailed deer (Odocoileus virginianus). Ticks Tick Borne Dis. 2013, 4, 110-119. [CrossRef]

29. Lbacha, A.H.; Zouagui, Z.; Alali, S.; Rhalem, A.; Petit, E.; Ducrotoy, M.J.; Boulouis, H.-J.; Maillard, R. “Candidatus anaplasma camelii" in one-humped camels (Camelus dromedarius) in Morocco: A novel and emerging Anaplasma species? Infect. Dis. Poverty 2017, 6, 1-8. [CrossRef] [PubMed]

30. Gofton, A.W.; Hair, S.; Ryan, U.; Irwin, P. Initial detection of Ehrlichia mineirensis and 'Candidatus Anaplasma boleense' in an Australian steer. Mol. Genet. Genom. 2018, 5, 119.

31. Dahmani, M.; Davoust, B.; Sambou, M.; Bassene, H.; Scandola, P.; Ameur, T.; Raoult, D.; Fenollar, F.; Mediannikov, O. Molecular investigation and phylogeny of species of the Anaplasmataceae infecting animals and ticks in Senegal. Parasit. Vectors 2019, 12, 495. [CrossRef] [PubMed]

32. Vanstreels, R.E.T.; Yabsley, M.J.; Parsons, N.J.; Swanepoel, L.; Pistorius, P.A. A novel candidate species of Anaplasma that infects avian erythrocytes. Parasit. Vectors 2018, 11, 1-7. [CrossRef] [PubMed]

33. Guo, W.P.; Tian, J.H.; Lin, X.D.; Ni, X.B.; Chen, X.P.; Liao, Y.; Yang, S.Y.; Dumler, J.S.; Holmes, E.C.; Zhang, Y.Z. Extensive genetic diversity of Rickettsiales bacteria in multiple mosquito species. Sci. Rep. 2016, 6, 1-11. [CrossRef]

34. Diaz-Sanchez, S.; Hernández-Jarguín, A.; de Mera, I.G.F.; Alberdi, P.; Zweygarth, E.; Gortazar, C.; de la Fuente, J. Draft genome sequences of Anaplasma phagocytophilum, A. marginale, and A. ovis Isolates from different hosts. Genome Announc. 2018, 6, e01503-e01517. [CrossRef] [PubMed]

35. Llanes, A.; Rajeev, S. First whole genome sequence of Anaplasma platys, an obligate intracellular rickettsial pathogen of dogs. Pathogens 2020, 9, 277. [CrossRef] [PubMed]

36. Chochlakis, D.; Ioannou, I.; Tselentis, Y.; Psaroulaki, A. Human anaplasmosis and Anaplasma ovis variant. Emerg. Infect. Dis. 2010, 16, 1031-1032. [CrossRef]

37. Rar, V.; Golovljova, I. Anaplasma, Ehrlichia, and “Candidatus Neoehrlichia” bacteria, pathogenicity, biodiversity, and molecular genetic characteristics, a review. Infect. Genet. Evol. 2011, 11, 1842-1861. [CrossRef] [PubMed]

38. Weisburg, W.G.; Barns, S.M.; Pelletier, D.A.; Lane, D.J. 16 S ribosomal DNA amplification for phylogenetic study. J. Bacteriol. 1991, 173, 697-703. [CrossRef]

39. Sumner, J.W.; Nicholson, W.L.; Massung, R.F. PCR amplification and comparison of nucleotide sequences from the groESL heat shock operon of Ehrlichia species. J. Clin. Microbiol. 1997, 35, 2087-2092. [CrossRef]

40. Dumler, J.S.; Barbet, A.F.; Bekker, C.P.; Dasch, G.A.; Palmer, G.H.; Ray, S.C.; Rikihisa, Y.; Rurangirwa, F.R. Reorganization of genera in the families Rickettsiaceae and Anaplasmataceae in the order Rickettsiales: Unification of some species of Ehrlichia with Anaplasma, Cowdria with Ehrlichia and Ehrlichia with Neorickettsia, descriptions of six new species combinations and designation of Ehrlichia equi and 'HGE agent' as subjective synonyms of Ehrlichia phagocytophila. Int. J. Syst. Evol. Microbiol. 2001, 51, 2145-2165. [PubMed]

41. Carrade, D.D.; Foley, J.E.; Borjesson, D.L.; Sykes, J.E. Canine granulocytic anaplasmosis: A review. J. Vet. Intern. Med. 2009, 23, 1129-1141. [CrossRef] [PubMed]

42. Berger, S. Anaplasmosis, Global Status; Gideon Informatics. Inc.: Los Angeles, CA, USA, 2021. Available online: https://www. gideononline.com/ebooks/disease/anaplasmosis-global-status/ (assessed on 11 August 2021).

43. Lima, M.L.; Soares, P.T.; Ramos, C.A.; Araújo, F.R.; Ramos, R.A.; Souza, I.I.; Faustino, M.A.; Alves, L.C. Molecular detection of Anaplasma platys in a naturally-infected cat in Brazil. Braz. J. Microbiol. 2010, 41, 381-385. [CrossRef] [PubMed]

44. Kocan, K.M.; de la Fuente, J.; Guglielmone, A.A.; Melendez, R.D. Antigens and Alternatives for Control of Anaplasma marginale Infection in Cattle. Clin. Microbiol. Rev. 2003, 16, 698-712. [CrossRef]

45. Arraga-Alvarado, C.M.; Qurollo, B.A.; Parra, O.C.; Berrueta, M.A.; Hegarty, B.C.; Breitschwerdt, E.B. Case report: Molecular evidence of Anaplasma platys infection in two women from Venezuela. Am. J. Trop. Med. Hyg. 2014, 91, 1161-1165. [CrossRef] [PubMed] 
46. Sainz, A.; Amusategui, I.; Tesouro, M.A. Ehrlichia platys infection and disease in dogs in Spain. J. Vet. Diagn. Investig. 1999, 11, 382-384. [CrossRef]

47. Suksawat, J.; Xuejie, Y.; Hancock, S.I.; Hegarty, B.C.; Nilkumhang, P.; Breitschwerdt, E.B. Serologic and molecular evidence of coinfection with multiple vector-borne pathogens in dogs from Thailand. J. Vet. Intern. Med. 2001, 15, 453-462. [CrossRef]

48. Sparagano, O.A.E.; Vos, A.P.d.; Paoletti, B.; Camma, C.; Santis, P.d.; Otranto, D.; Giangaspero, A. Molecular detection of Anaplasma platys in dogs using polymerase chain reaction and reverse line blot hybridization. J. Vet. Diagn. Investig. 2003, 15, 527-534. [CrossRef]

49. Brown, R.N.; Lane, R.; Dennis, D.T. Geographic distributions of tick-borne diseases and their Vectors. Tick Borne Dis. Humans 2005, 21, 363-391.

50. Aguirre, E.; Tesouro, M.A.; Ruiz, L.; Amusategui, I.; Sainz, A. Genetic characterization of Anaplasma (Ehrlichia) platys in dogs in Spain. J. Vet. Med. Ser. B. 2006, 53, 197-200. [CrossRef]

51. Melo, A.L.T.; Witter, R.; Martins, T.F.; Pacheco, T.A.; Alves, A.S.; Chitarra, C.S.; Aguiar, D.M. A survey of tick-borne pathogens in dogs and their ticks in the Pantanal biome, Brazil. Med. Vet. Entomol. 2016, 30, 112-116. [CrossRef] [PubMed]

52. Sudan, V.; Sharma, R.L.; Borah, M.K. Subclinical anaplasmosis in camel (Camelus dromedarius) and its successful therapeutic management. J. Parasit. Dis. 2014, 38, 163-165. [CrossRef]

53. Lorusso, V.; Wijnveld, M.; Majekodunmi, A.O.; Dongkum, C.; Fajinmi, A.; Dogo, A.G.; Thrusfield, M.; Mugenyi, A.; Vaumourin, E.; Igweh, A.C.; et al. Tick-borne pathogens of zoonotic and veterinary importance in Nigerian cattle. Parasit. Vectors 2016, 9, 217-226. [CrossRef] [PubMed]

54. Bahrami, S.; Hamidinejat, H.; Tafreshi, A.R.G. First molecular detection of Anaplasma Phagocytophilum in Dromedaries ( Camelus Dromedarius). J. Zoo Wildl. Med. 2018, 49, 844-848. [PubMed]

55. Woldehiwet, Z. Anaplasma phagocytophilum in ruminants in Europe. Ann. N. Y. Acad. Sci. 2006, 1078, 446-460. [CrossRef]

56. Dahlgren, F.S.; Mandel, E.J.; Krebs, J.W.; Massung, R.F.; McQuiston, J.H. Increasing incidence of Ehrlichia chaffeensis and Anaplasma phagocytophilum in the United States, 2000-2007. Am. J. Trop. Med. Hyg. 2011, 85, 124-131. [CrossRef]

57. Bakken, J.S.; Dumler, J.S. Human granulocytic anaplasmosis. Infect. Dis. Clin. 2015, 29, 341-355. [CrossRef]

58. Fishbein, D.B.; Raoult, D. A cluster of Coxiella burnetii infections associated with exposure to vaccinated goats and their unpasteurized dairy products. Am. J. Trop. Med. Hyg. 1992, 47, 35-40. [CrossRef] [PubMed]

59. Dumler, J.S.; Bakken, J.S. Human ehrlichioses: Newly recognized infections transmitted by ticks. Annu. Rev. Med. 1998, 49, 201-213. [CrossRef]

60. Blanco, J.R.; Oteo, J.A. Human granulocytic ehrlichiosis in Europe. Clin. Microbiol. Infect. 2002, 8, 763-772. [CrossRef]

61. Woldehiwet, Z. The natural history of Anaplasma phagocytophilum. Vet. Parasitol. 2010, 167, 108-122. [CrossRef]

62. Do, T.; Phoosangwalthong, P.; Kamyingkird, K.; Kengradomkij, C.; Chimnoi, W.; Inpankaew, T. Molecular detection of tick-borne pathogens in stray dogs and Rhipicephalus sanguineus sensu lato ticks from Bangkok, Thailand. Pathogens 2021, 10, 561. [CrossRef]

63. Piratae, S.; Senawong, P.; Chalermchat, P.; Harnarsa, W.; Sae-Chue, B. Molecular evidence of Ehrlichia canis and Anaplasma platys and responses in naturally infected dogs in Kalasin, Thailand. Vet. World. 2019, 12, 131-135. [CrossRef]

64. Buddhachat, K.; Meerod, T.; Pradit, W.P.S.; Chomdej, S.; Nganvongpanit, K. Simultaneous differential detection of canine blood parasites: Multiplex high-resolution melting analysis (mHRM). Ticks Tick Borne Dis. 2020, 11, 101370. [CrossRef] [PubMed]

65. Alhassan, A.; Hove, P.; Sharma, B.; Matthew-Belmar, V.; Karasek, I.; Lanza-Perea, M.; Werners, A.H.; Wilkerson, M.J.; Ganta, R.R. Molecular detection and characterization of Anaplasma platys and Ehrlichia canis in dogs from the Caribbean. Ticks Tick Borne Dis. 2021, 12, 101727. [CrossRef] [PubMed]

66. Wilkerson, M.J.; Black, K.E.; Lanza-Perea, M.; Sharma, B.; Gibson, K.; Stone, D.M.; George, A.; Nair, A.D.; Ganta, R.R. Initial development and preliminary evaluation of a multiplex bead assay to detect antibodies to Ehrlichia canis, Anaplasma platys, and Ehrlichia chaffeensis outer membrane peptides in naturally infected dogs from Grenada, West Indies. J. Vet. Diagn. Investig. 2017, 29, 109-114. [CrossRef] [PubMed]

67. Sharma, B.; Ganta, R.; Stone, D.; Alhassan, A.; Lanza-Perea, M.; Matthew Belmar, V.; Karasek, I.; Cooksey, E.M.; Butler, C.; Gibson, K.; et al. Development of a multiplex pcr and magnetic dna capture assay for detecting six species pathogens of the genera Anaplasma and Ehrlichia in canine, bovine, caprine and ovine blood samples from Grenada, West Indies. Pathogens 2021, 10, 192. [CrossRef]

68. Georges, K.; Ezeokoli, C.D.; Newaj-Fyzul, A.; Campbell, M.; Mootoo, N.; Mutani, A.; Sparagano, O.A. The application of PCR and reverse line blot hybridization to detect arthropod-borne hemopathogens of dogs and cats in Trinidad. Ann. N. Y. Acad. Sci. 2008, 1149, 196-199. [CrossRef]

69. Ghauri, H.N.; Ijaz, M.; Ahmed, A.; Muhammad Naveed, M.U.A.; Nawab, Y.; Javed, M.U.; Ghaffar, A. Molecular investigation and phylogenetic analysis of anaplasmosis in dogs. J. Parasitol. 2021, 107, 295-303. [CrossRef]

70. Pérez-Macchi, S.; Pedrozo, R.; Bittencourt, P.; Müller, A. Prevalence, molecular characterization and risk factor analysis of Ehrlichia canis and Anaplasma platys in domestic dogs from Paraguay. Comp. Immunol. Microbiol. Infect. Dis. 2019, 62, 31-39. [CrossRef]

71. Pesapane, R.; Foley, J.; Thomas, R.; Castro, L.R. Molecular detection and characterization of Anaplasma platys and Ehrlichia canis in dogs from northern Colombia. Vet. Microbiol. 2019, 233, 184-189. [CrossRef]

72. Kontos, V.I.; Papadopoulos, O.; French, T.W. Natural and experimental canine infections with a Greek strain of Ehrlichia platys. Vet. Clin. Pathol. 1991, 20, 101-105. [CrossRef] 
73. Faizal, M.D.; Haryanto, A.; Tjahajati, I. Diagnosis and molecular characterization of Anaplasma platys in dog patients in Yogyakarta area, Indonesia. Indones. J. Biotechnol. 2019, 24, 43-50. [CrossRef]

74. Götsch, S.; Leschnik, M.; Duscher, G.; Burgstaller, J.P.; Wille-Piazzai, W.; Joachim, A. Ticks and haemoparasites of dogs from Praia, Cape Verde. Vet. Parasitol. 2009, 166, 171-174. [CrossRef] [PubMed]

75. de Caprariis, D.; Dantas-Torres, F.; Capelli, G.; Mencke, N.; Stanneck, D.; Breitschwerdt, E.B.; Otranto, D. Evolution of clinical, haematological and biochemical findings in young dogs naturally infected by vector-borne pathogens. Vet. Microbiol. 2011, 21, 206-212. [CrossRef] [PubMed]

76. Ramos, R.A.; Latrofa, M.S.; Giannelli, A.; Lacasella, V.; Campbell, B.E.; Dantas-Torres, F.; Otranto, D. Detection of Anaplasma platys in dogs and Rhipicephalus sanguineus group ticks by a quantitative real-time PCR. Vet. Parasitol. 2014, 205, 285-288. [CrossRef]

77. Dyachenko, V.; Pantchev, N.; Balzer, H.J.; Meyersen, A.; Straubinger, R.K. First case of Anaplasma platys infection in a dog from Croatia. Parasite Vector. 2012, 5, 49. [CrossRef]

78. Barker, E.N.; Langton, D.A.; Helps, C.R.; Brown, G.; Malik, R.; Shaw, S.E.; Tasker, S. Haemoparasites of free-roaming dogs associated with several remote Aboriginal communities in Australia. BMC Vet. Res. 2012, 8, 1-7. [CrossRef] [PubMed]

79. Hii, S.F.; Traub, R.J.; Thompson, M.F.; Henning, J.; O’Leary, C.A.; Burleigh, A.; Kopp, S.R. Canine tick-borne pathogens and associated risk factors in dogs presenting with and without clinical signs consistent with tick-borne diseases in northern Australia. Aust. Vet. J. 2015, 93, 58-66. [CrossRef] [PubMed]

80. Andersson, M.; Turcitu, M.A.; Stefanache, M.; Tamba, P.; Barbuceanu, F.; Chitimia, L. First evidence of Anaplasma platys and Hepatozoon canis co-infection in a dog from Romania-a case report. Ticks TickBorne Dis. 2013, 4, 317-319. [CrossRef]

81. Kelly, P.J.; Lucas, H.; Eremeeva, M.E.; Dirks, K.G.; Rolain, J.M.; Yowell, C.; Thomas, R.; Douglas, T.; Dasch, G.A.; Raoult, D. Rickettsia felis, West Indies. Emerg. Infect. Dis. 2010, 16, 570-571. [CrossRef]

82. Wei, L.; Kelly, P.; Ackerson, K.; Zhang, J.; El-Mahallawy, H.S.; Kaltenboeck, B.; Wang, C. First report of Babesia gibsoni in Central America and survey for vector-borne infections in dogs from Nicaragua. Parasit. Vectors 2014, 7, 1-6. [CrossRef]

83. Qurollo, B.A.; Chandrashekar, R.; Hegarty, B.C.; Beall, M.J.; Stillman, B.A.; Liu, J.; Thatcher, B.; Pultorak, E.; Cerrito, B.; Walsh, M.; et al. A serological survey of tick-borne pathogens in dogs in North America and the Caribbean as assessed by Anaplasma phagocytophilum, A. platys, Ehrlichia canis, E. chaffeensis, E. ewingii, and Borrelia burgdorferi species-specific peptides. Infect. Ecol. Epidemiol. 2014, 4, 24699. [CrossRef]

84. Almazán, C.; González-Álvarez, V.H.; de Mera, I.G.F.; Cabezas-Cruz, A.; Rodríguez-Martínez, R.; de la Fuente, J. Molecular identification and characterization of Anaplasma platys and Ehrlichia canis in dogs in Mexico. Ticks TickBorne Dis. 2016, 7, 276-283. [CrossRef] [PubMed]

85. Aktas, M.; Altay, K.; Dumanli, N.; Kalkan, A. Molecular detection and identification of Ehrlichia and Anaplasma species in ixodid ticks. Parasitol. Res. 2009, 104, 1243-1248. [CrossRef] [PubMed]

86. Bonilla, M.C.; Campos-Calderón, L.; Jiménez-Rocha, A.E.; Romero-Zúñiga, J.J.; Alberti, A.; Zobba, R.; Dolz, G. Characterization of Anaplasma spp. infection in dogs from Costa Rica. Vet. Parasitol. Reg. Stud. Rep. 2017, 8, 60-65. [CrossRef] [PubMed]

87. Soares, R.; Ramos, C.A.; Pedroso, T.; Babo-Terra, V.; Cleveland, H.; Araújo, F. Molecular survey of Anaplasma platys and Ehrlichia canis in dogs from Campo Grande, Mato Grosso do Sul, Brazil. Acad. Bras. Cienc. 2017, 89, 301-306. [CrossRef]

88. da Silva, G.C.; Benitez, A.; Girotto, A.; Taroda, A.; Vidotto, M.C.; Garcia, J.L.; de Freitas, J.C.; Arlington, S.H.; Vidotto, O. Occurrence of Ehrlichia canis and Anaplasma platys in household dogs from northern Parana. Rev. Bras. Parasitol. Vet. 2012, 12, 379-385. [CrossRef] [PubMed]

89. Lasta, C.S.; dos Santos, A.P.; Messick, J.B.; Oliveira, S.T.; Biondo, A.W.; Vieira, R.F.; Dalmolin, M.L.; González, F.H. Molecular detection of Ehrlichia canis and Anaplasma platys in dogs in Southern Brazil. Rev. Bras. Parasitol. Vet. 2013, 22, 360-366. [CrossRef]

90. McCown, M.E.; Alleman, A.; Sayler, K.A.; Chandrashekar, R.; Thatcher, B.; Tyrrell, P.; Stillman, B.; Beall, M.; Barbet, A.F. Point prevalence survey for tick-borne pathogens in military working dogs, shelter animals, and pet populations in northern Colombia. J. Spec. Oper. Med. 2014, 14, 81-85.

91. Zaid, T.; Ereqat, S.; Nasereddin, A.; Al-Jawabreh, A.; Abdelkader, A.; Abdeen, Z. Molecular characterization of AnaplasmaandEhrlichiain ixodid ticks and reservoir hosts from Palestine: A pilot survey. Vet. Med. Sci. 2019, 5, 230-242. [CrossRef] [PubMed]

92. Yang, B.; Ye, C.; Sun, E.; Wen, Y.; Qian, D.; Sun, H. First molecular evidence of Anaplasma spp. co-infection in stray dogs from Anhui, China. Acta. Trop. 2020, 206, 105453. [CrossRef]

93. Cicuttin, G.; Boeri, E.; Beltrán, F.; Gury, D.; Federico, E. Molecular detection of Neorickettsiaristicii in Brazilian free-tailed bats (Tadaridabrasiliensis) from Buenos Aires, Argentina. Pesq. Vet. Bras. 2013, 33, 648-650. [CrossRef]

94. Springer, A.; Montenegro, V.; Schicht, S.; Wölfel, S.; Schaper, S.; Chitimia-Dobler, L.; Siebert, S.; Strube, C. Detection of Rickettsia monacensis and Rickettsia amblyommatis in ticks collected from dogs in Costa Rica and Nicaragua. Ticks Tick Borne Dis. 2018, 9 , 1565-1572. [CrossRef] [PubMed]

95. Hmoon, M.M.; Htun, L.L.; Thu, M.J.; Chel, H.M.; Thaw, Y.N.; Win, S.Y.; Chan Soe, N.; Khaing, Y.; Thein, S.S.; Bawm, S. Molecular prevalence and identification of Ehrlichia canis and Anaplasma platys from Dogs in Nay Pyi Taw Area, Myanmar. Vet. Med. Int. 2021, 20, 8827206. [CrossRef] [PubMed]

96. Chatanga, E.; Kainga, H.; Razemba, T.; Ssuna, R.; Swennen, L.; Hayashida, K.; Sugimoto, C.; Katakura, K.; Nonaka, N.; Nakao, R. Molecular detection and characterization of tick-borne hemoparasites and Anaplasmataceae in dogs in major cities of Malawi. Parasitol. Res. 2021, 120, 267-276. [CrossRef] 
97. Jimenez, I.A.; Vega Mariño, P.A.; Stapleton, G.S.; Prieto, J.B.; Bowman, D.D. Canine vector-borne disease in domestic dogs on Isla Santa Cruz, Galápagos. Vet. Parasitol. Reg. Stud. Rep. 2020, 19, 100373. [CrossRef]

98. Alanazi, A.; Nguyen, V.; Alyousif, M.; Manoj, R.; Alouffi, A.; Donato, R.; Sazmand, A.; Mendoza-Roldan, J.; Torres, F.; Otranto, D. Ticks and associated pathogens in camels (Camelus dromedarius) from Riyadh Province, Saudi Arabia. Parasit. Vectors 2020, 13, 1-9. [CrossRef] [PubMed]

99. Diakou, A.; Di Cesare, A.; Morelli, S.; Colombo, M.; Halos, L.; Simonato, G.; Tamvakis, A.; Beugnet, F.; Paoletti, B.; Traversa, D. Endoparasites and vector-borne pathogens in dogs from Greek islands: Pathogen distribution and zoonotic implications. PLoS Negl. Trop. Dis. 2019, 13, e0007003. [CrossRef]

100. Licari, E.; Takács, N.; Solymosi, N.; Farkas, R. First detection of tick-borne pathogens of dogs from Malta. Ticks TickBorne Dis. 2017, 8, 396-399. [CrossRef]

101. Starkey, L.A.; Newton, K.; Brunker, J.; Crowdis, K.; Edourad, E.; Meneus, P.; Little, S.E. Prevalence of vector-borne pathogens in dogs from Haiti. Vet. Parasitol. 2016, 224, 7-12. [CrossRef]

102. Huggins, L.G.; Colella, V.; Koehler, A.V.; Schunack, B.; Traub, R.J. A multipronged next-generation sequencing metabarcoding approach unearths hyperdiverse and abundant dog pathogen communities in Cambodia. Transbound. Emerg. Dis. 2021, 10. [CrossRef]

103. Proboste, T.; Kalema-Zikusoka, G.; Altet, L.; Solano-Gallego, L.; Fernández de Mera, I.G.; Chirife, A.D.; Muro, J.; Bach, E.; Piazza, A.; Cevidanes, A.; et al. Infection and exposure to vector-borne pathogens in rural dogs and their ticks, Uganda. Parasit. Vectors 2015, 8, 306. [CrossRef]

104. Hamel, D.; Shukullari, E.; Rapti, D.; Silaghi, C.; Pfister, K.; Rehbein, S. Parasites and vector-borne pathogens in clientowned dogs in Albania. Blood pathogens and seroprevalences of parasitic and other infectious agents. Parasitol. Res. 2016, 115, 489-499. [CrossRef]

105. Kamani, J.; Morick, D.; Mumcuoglu, K.; Harrus, S. Prevalence and diversity of Bartonella species in commensal rodents and ectoparasites from Nigeria, West Africa. PLoS Neglect. Trop. Dis. 2013, 7, e2246. [CrossRef]

106. Alho, A.M.; Lima, C.; Latrofa, M.S.; Colella, V.; Ravagnan, S.; Capelli, G.; Madeira de Carvalho, L.; Cardoso, L.; Otranto, D. Molecular detection of vector-borne pathogens in dogs and cats from Qatar. Parasit. Vectors 2017, 10, 298. [CrossRef]

107. Modarelli, J.J.; Tomeček, J.M.; Piccione, J.; Ferro, P.J.; Esteve-Gasent, M.D. Molecular prevalence and ecoregion distribution of select tick-borne pathogens in Texas dogs. Transbound. Emerg. Dis. 2019, 66, 1291-1300. [CrossRef] [PubMed]

108. Manoj, R.; Iatta, R.; Latrofa, M.S.; Capozzi, L.; Raman, M.; Colella, V.; Otranto, D. Canine vector-borne pathogens from dogs and ticks from Tamil Nadu, India. Acta. Trop. 2020, 203, 105308. [CrossRef]

109. Motoi, Y.; Satoh, H.; Inokuma, H.; Kiyuuna, T.; Muramatsu, Y.; Ueno, H.; Morita, C. First detection of Ehrlichia platys in dogs and ticks in Okinawa, Japan. Microbiol. Immunol. 2001, 45, 89-91. [CrossRef] [PubMed]

110. Baldridge, G.D.; Scoles, G.; Burkhardt, N.Y.; Schloeder, B.; Kurtti, T.J.; Munderloh, U.G. Transovarial transmission of Francisellalike endosymbionts and Anaplasma phagocytophilum variants in Dermacentor albipictus (Acari: Ixodidae). J. Med. Entomol. 2009, 46, 625-632. [CrossRef]

111. Dugat, T.; Lagrée, A.C.; Maillard, R.; Boulouis, H.J.; Haddad, N. Opening the black box of Anaplasma phagocytophilum diversity: Current situation and future perspectives. Front. Cell. Infect. Microbiol. 2015, 5, 61. [CrossRef]

112. Fine, A.B.; Sweeney, J.D.; Nixon, C.P.; Knoll, B.M. Transfusion-transmitted anaplasmosis from a leukoreduced platelet pool. Transfusion 2016, 56, 699-704. [CrossRef] [PubMed]

113. Ahmed, S.S.; Khalaf, J.M. First identification of Anaplasma platys and Anaplasma phagocytophlium in the blood of dogs in Baghdad Governorate. Plant Arch. 2020, 20, 393-397.

114. Yousefi, A.M.R.C.; Golmohammadi, A.; Azami, S. Molecular detection of Anaplasma Phagocytophilum as a zoonotic agent in owned and stray dogs in Tehran, Iran. Arch. Razi. Inst. 2019, 74, 33-38.

115. Rojero-Vázquez, E.; Gordillo-Pérez, G.; Weber, M. Infection of Anaplasma phagocytophilum and Ehrlichia spp. in opossums and dogs in Campeche, Mexico: The role of tick infestation. Front. Ecol. Evol. 2017, 5, 161-163. [CrossRef]

116. Henn, J.B.; Gabriel, M.W.; Kasten, R.W.; Brown, R.N.; Theis, J.H.; Foley, J.E.; Chomel, B.B. Gray foxes (Urocyon cinereoargenteus) as a potential reservoir of a Bartonella clarridgeiae-like bacterium and domestic dogs as part of a sentinel system for surveillance of zoonotic arthropod-borne pathogens in northern California. J. Clin. Microbiol. 2007, 45, 2411-2418. [CrossRef] [PubMed]

117. Santos, H.A.; Pires, M.S.; Vilela, J.A.; Santos, T.M.; Faccini, J.L.; Baldani, C.D.; Thomé, S.M.; Sanavria, A.; Massard, C.L. Detection of Anaplasma phagocytophilum in Brazilian dogs by real-time polymerase chain reaction. J. Vet. Diagn. Investing. 2011, 23, 770-774. [CrossRef] [PubMed]

118. Elfving, K.; Malmsten, J.; Dalin, A.M.; Nilsson, K. Serologic and Molecular Prevalence of Rickettsia helvetica and Anaplasma phagocytophilum in Wild Cervids and Domestic Mammals in the Central Parts of Sweden. Vector Borne Zoonotic Dis. 2015, 15, 529-533. [CrossRef] [PubMed]

119. Vargas-Hernandez, G.; André, M.R.; Cendales, D.M.; de Sousa, K.C.M.; Gonçalves, L.R.; Rondelli, M.C.H.; Machado, R.Z.; TinucciCosta, M. Molecular detection of Anaplasma species in dogs in Colombia. Rev. Bras. Parasitol. Vet. 2016, 25, 459-464. [CrossRef]

120. Çetinkaya, H.; Matur, E.; Akyazi, İ.; Ekiz, E.E.; Aydin, L.; Toparlak, M. Serological and molecular investigation of Ehrlichia spp. and Anaplasma spp. in ticks and blood of dogs, in the Thrace Region of Turkey. Ticks Tick Borne Dis. 2016, 7, 706-714. [CrossRef] [PubMed]

121. Rikihisa, Y. The tribe Ehrlichieae and ehrlichial diseases. Clin. Microbiol. Rev. 1991, 4, 286-308. [CrossRef] 
122. Latrofa, M.S.; Dantas-Torres, F.; deCaprariis, D.; Cantacessi, C.; Capelli, G.; Lia, R.P.; Breitschwerdt, E.B.; Otranto, D. Vertical transmission of Anaplasma platys and Leishmania infantum in dogs during the first half of gestation. Parasit. Vector. 2016, 9, 269-275. [CrossRef]

123. Matei, I.A.; D’Amico, G.; Yao, P.K.; Ionică, A.M.; Kanyari, P.W.N.; Daskalaki, A.A.; Dumitrache, M.O.; Sándor, A.D.; Gherman, C.M.; Qablan, M.; et al. Molecular detection of Anaplasma platys infection in free-roaming dogs and ticks from Kenya and Ivory Coast. Parasit. Vectors 2016, 9, 157. [CrossRef] [PubMed]

124. Stuen, S.; Okstad, W.; Sagen, A.M. Intrauterine transmission of Anaplasma phagocytophilum in persistently infected lambs. Vet. Sci. 2018, 5, 25-29. [CrossRef] [PubMed]

125. Villar, M.; López, V.; Ayllón, N.; Cabezas-Cruz, A.; López, J.A.; Vázquez, J.; Alberdi, P.; de la Fuente, J. The intracellular bacterium Anaplasma phagocytophilum selectively manipulates the levels of vertebrate host proteins in the tick vector Ixodes scapularis. Parasit. Vectors 2016, 9, 1-17. [CrossRef] [PubMed]

126. Snellgrove, A.N.; Krapiunaya, I.; Ford, S.L.; Stanley, H.M.; Wickson, A.G.; Hartzer, K.L.; Levin, M.L. Vector competence of Rhipicephalus sanguineus sensu stricto for Anaplasma platys. Ticks Tick Borne Dis. 2020, 11, 101517. [CrossRef]

127. De Tommasi, A.S.; Baneth, G.; Breitschwerdt, E.B.; Stanneck, D.; Dantas-Torres, F.; Otranto, D.; de Caprariis, D. Anaplasmaplatys in bone marrow megakaryocytes of young dogs. J. Clin. Microbial. 2014, 52, 2231-2234. [CrossRef]

128. Rikihisa, Y. Mechanisms of obligatory intracellular infection with Anaplasma phagocytophilum. Clin. Microbiol. Rev. 2011, 24, 469-489. [CrossRef] [PubMed]

129. Bradfield, J.F.; Vore, S.J.; Pryor, W.H.J. Ehrlichia platys infection in dogs. Lab. Anim. Sci. 1996, 46, 565-568.

130. Bouzouraa, T.; René-Martellet, M.; Chêne, J.; Attipa, C.; Lebert, I.; Chalvet-Monfray, K.; Cadoré, J.L.; Halos, L.; Chabanne, L. Clinical and laboratory features of canine Anaplasma platys infection in 32 naturally infected dogs in the Mediterranean basin. Ticks Tick Borne Dis. 2016, 7, 1256-1264. [CrossRef]

131. Kohn, B.; Galke, D.; Beelitz, P.; Pfister, K. Clinical features of canine granulocytic anaplasmosis in 18 naturally infected dogs. J. Vet. Intern. Med. 2008, 22, 1289-1295. [CrossRef]

132. Nair, A.D.; Cheng, C.; Ganta, C.K.; Sanderson, M.W.; Alleman, A.R.; Munderloh, U.G.; Ganta, R.R. Comparative experimental infection study in dogs with Ehrlichia canis, E. chaffeensis, Anaplasma platys and A. phagocytophilum. PLoS ONE 2016, 11, e0148239.

133. Bjöersdorff, A.; Svendenius, L.; Owens, J.H.; Massung, R.F. Feline granulocytic ehrlichiosis-a report of a new clinical entity and characterisation of the infectious agent. J. Small Anim. Pract. 1999, 40, 20-24. [CrossRef] [PubMed]

134. Savidge, C.; Ewing, P.; Andrews, J.; Aucoin, D.; Lappin, M.R.; Moroff, S. Anaplasma phagocytophilum infection of domestic cats: 16 cases from the northeastern USA. J. Feline Med. Surg. 2016, 18, 85-91. [CrossRef] [PubMed]

135. Sim, R.R.; Joyner, P.H.; Padilla, L.R.; Anikis, P.; Aitken-Palmer, C. Clinical disease associated with Anaplasma phagocytophilum infection in captive Przewalski's horses (Equus ferus przewalskii). J. Zoo Wildl. Med. 2017, 48, 497-505. [CrossRef]

136. Ismail, N.; Bloch, K.C.; McBride, J.W. Human ehrlichiosis and anaplasmosis. Clin. Lab. Med. 2010, 30, $261-292$. [CrossRef] [PubMed]

137. El-Khoury, L.; Furie, R. Inflammatory arthritis: A unique presentation of human anaplasmosis. Clin. Rheumatol. 2019, 38, 257-259. [CrossRef]

138. Palmer, G.H.; Abbott, J.R.; French, D.M.; McElwain, T.F. Persistence of Anaplasma ovis infection and conservation of the msp-2 and msp-3 multigene families within the genus Anaplasma. Infect. Immun. 1998, 66, 6035-6039. [CrossRef]

139. Kocan, K.M.; de la Fuente, J.; Blouin, E.F.; Coetzee, J.F.; Ewing, S.A. The natural history of Anaplasma marginale. Vet. Parasitol. 2010, 167, 95-107. [CrossRef]

140. Eddlestone, S.M.; Gaunt, S.D.; Neer, T.M.; Boudreaux, C.M.; Gill, A.; Haschke, E.; Corstvet, R.E. PCR detection of Anaplasma platys in blood and tissue of dogs during acute phase of experimental infection. Exp. Parasitol. 2007, 115, 205-210. [CrossRef]

141. OIE. Bovine Anaplasmosis. In Manual of Diagnostic Tests and Vaccines for Terestrial Animals; OIE: Paris, France, 2015; Chapter 2.4.1.

142. Choi, S.; Cho, Y.U.; Kim, S.H. Morulae in neutrophils: A diagnostic clue for human granulocytic anaplasmosis. IDcases 2019, 15, e00506. [CrossRef]

143. Tokarz, R.; Tagliafierro, T.; Cucura, D.M.; Rochlin, I.; Sameroff, S.; Lipkin, W.I. Detection of Anaplasma phagocytophilum, Babesia microti, Borrelia burgdorferi, Borrelia miyamotoi and Powassan virus in ticks by a multiplex real-time reverse transcription-PCR assay. mSphere 2017, 2, e00151-17. [CrossRef]

144. Silaghi, C.; Santos, A.S.; Gomes, J.; Christova, I.; Matei, I.A.; Walder, G.; Domingos, A.; Bell-Sakyi, L.; Sprong, H.; von Loewenich, F.D.; et al. Guidelines for the direct detection of Anaplasma spp. in diagnosis and epidemiological studies. Vector Borne Zoonotic Dis. 2017, 17, 12-22. [CrossRef] [PubMed]

145. Hebels, D.G.; van Herwijnen, M.H.; Brauers, K.J.; de Kok, T.M.; Chalkiadaki, G.; Kyrtopoulos, S.A.; Kleinjans, J.C. Elimination of heparin interference during microarray processing of fresh and biobank-archived blood samples. Environ. Mol. Mutagen. 2014, 55, 482-491. [CrossRef]

146. Sanchez-Fito, M.T.; Oltra, E. Optimized treatment of heparinized blood fractions to make them suitable for analysis. Biopreserv. Biobank. 2015, 13, 287-295. [CrossRef]

147. Massung, R.F.; Slater, K.; Owens, J.H.; Nicholson, W.L.; Mather, T.N.; Solberg, V.B.; Olson, J.G. Nested PCR assay for detection of granulocytic ehrlichiae. J. Clin. Microbiol. 1998, 36, 1090-1095. [CrossRef] 
148. Gaunt, S.D.; Beall, M.J.; Stillman, B.A.; Lorentzen, L.; Diniz, P.P.V.P.; Chandrashekar, R.; Breitschwerdt, E.B. Experimental infection and co-infection of dogs with Anaplasma platys and Ehrlichia canis: Hematologic, serologic and molecular findings. Parasit. Vector. 2010, 3, 33-39. [CrossRef] [PubMed]

149. Szekeres, S.; Coipan, C.E.; Rigó, K.; Majoros, G.; Jahfari, S.; Sprong, H.; Földvári, G. Candidatus Neoehrlichia mikurensis and Anaplasma phagocytophilum in natural rodent and tick communities in Southern Hungary. Ticks TickBorne Dis. 2015, 6, 111-116. [CrossRef] [PubMed]

150. Njiru, Z.K. Loop-mediated isothermal amplification technology: Towards point of care diagnostics. PLoS Negl. Trop. Dis. 2012, 10, e0004348. [CrossRef] [PubMed]

151. Lee, C.; Lin, Y.; Tsang, C.; Chung, Y. A loop-mediated isothermal amplification (LAMP) assay for rapid detection of Anaplasma phagocytophilum infection in dogs. Turk. J. Vet. Anim. Sci. 2012, 36, 205-210.

152. Li, H.T.; Sun, L.S.; Chen, Z.M.; Hu, J.S.; Ye, C.D.; Jia, K.; Wang, H.; Yuan, L.G.; Zhang, G.H.; Li, S. Detection of Anaplasma platys in dogs using real-time loop-mediated isothermal amplification. Vet. J. 2014, 199, 468-470. [CrossRef]

153. Nelson, C.M.; Herron, M.J.; Felsheim, R.F.; Schloeder, B.R.; Grindle, S.M.; Chavez, A.O.; Kurtti, T.J.; Munderloh, U.G. Whole genome transcription profiling of Anaplasma phagocytophilum in human and tick host cells by tiling array analysis. BMC Genomics 2008, 9, 364. [CrossRef]

154. Munderloh, U.G.; Lynch, M.J.; Herron, M.J.; Palmer, A.T.; Kurtti, T.J.; Nelson, R.D.; Goodman, J.L. Infection of endothelial cells with Anaplasma marginale and A. phagocytophilum. Vet. Microbiol. 2004, 101, 53-64. [CrossRef] [PubMed]

155. Shimada, M.; Takamoto, N.; Su, H.; Sasahara, H.; Shimamura, Y.; Ando, S.; Ohashi, N. Predomination shift of different P44-expressing Anaplasma phagocytophilum in infected HL-60, THP-1, NB4, and RF/6A cell lines. Jpn. J. Infect. Dis. 2018, 72, 73-80. [CrossRef]

156. Massung, R.F.; Levin, M.L.; Munderloh, U.G.; Silverman, D.J.; Lynch, M.J.; Gaywee, J.K.; Kurtti, T.J. Isolation and propagation of the Ap-Variant 1 strain of Anaplasma phagocytophilum in a tick cell line. J. Clin. Microbiol. 2007, 45, 2138-2143. [CrossRef] [PubMed]

157. Bell-Sakyi, L.; Darby, A.; Baylis, M.; Makepeace, B.L. The Tick Cell Biobank: A global resource for in vitro research on ticks, other arthropods and the pathogens they transmit. Ticks TickBorne Dis. 2018, 9, 1364-1371. [CrossRef] [PubMed]

158. Monteiro, C.; Vale, F.L.; Vieira, M.S.; Perinotto, W.M.D.S.; Auad, A.M.; Dolisnki, C.; Furlong, J.; Bittencourt, V.R.E.P.; Cristina de Azevedo Prata, M. Efficacy of Heterorhabditis baujardi (Rhabditida: Heterorhabditidae) against Rhipicephalus microplus (Acari: Ixodidae) in presence of susceptible and alternate insect hosts. Biocontrol Sci. Technol. 2020, 30, 1316-1329. [CrossRef]

159. Samish, M.; Ginsberg, H.; Glazer, I. Biological control of ticks. J. Parasitol. 2004, 129, S389-S403. [CrossRef]

160. Ben Said, M.; Galai, Y.; Canales, M.; Nijhof, A.M.; Mhadhbi, M.; Jedidi, M.; de la Fuente, J.; Darghouth, M.A. Hd86, the Bm86 tick protein ortholog in Hyalomma scupense (syn. H. detritum): Expression in Pichia pastoris and analysis of nucleotides and amino acids sequences variations prior to vaccination trials. Vet. Parasitol. 2012, 183, 215-223. [PubMed]

161. Galai, Y.; Canales, M.; Saïd, M.B.; Gharbi, M.; Mhadhbi, M.; Jedidi, M.; de la Fuente, J.; Darghouth, M.A. Efficacy of Hyalomma scupense (Hd86) antigen against Hyalomma excavatum and H. scupense tick infestations in cattle. Vaccine 2012, 30, 7084-7089. [CrossRef]

162. Bhowmick, B.; Han, Q. Understanding tick biology and its implications in anti-tick and transmission blocking vaccines against tick-borne pathogens. Front. Vet. Sci. 2020, 7, 319-322. [CrossRef] [PubMed]

163. Contreras, M.; Villar, M.; De La Fuente, J. A vaccinomics approach for the identification of tick protective antigens for the control of Ixodes ricinus and Dermacentor reticulatus infestations in companion animals. Front. Physiol. 2019, 10, 977. [CrossRef]

164. De La Fuente, J.; Blouin, E.F.; Manzano-Roman, R.; Naranjo, V.; Almazán, C.; De La Lastra, J.M.P.; Zivkovic, Z.; Massung, R.F.; Jongejan, F.; Kocan, K.M. Differential expression of the tick protective antigen subolesin in Anaplasma marginale and A. phagocytophilum infected host cells. Ann. N. Y. Acad. Sci. 2008, 1149, 27-35. [CrossRef]

165. de la Fuente, J.; Ayoubi, P.; Blouin, E.F.; Almazán, C.; Naranjo, V.; Kocan, K.M. Anaplasmosis: Focusing on host-vector-pathogen interactions for vaccine development. Ann. N. Y. Acad. Sci. 2006, 1078, 416-423. [CrossRef]

166. Ojogun, N.; Kahlon, A.; Ragland, S.A.; Troese, M.J.; Mastronunzio, J.E.; Walker, N.J.; VieBrock, L.; Thomas, R.J.; Borjesson, D.L.; Fikrig, E.; et al. Anaplasma phagocytophilum outer membrane protein A interacts with sialylated glycoproteins to promote infection of mammalian host cells. Infect. Immun. 2012, 80, 3748-3760. [CrossRef]

167. Kahlon, A.; Ojogun, N.; Ragland, S.A.; Seidman, D.; Troese, M.J.; Ottens, A.K.; Fikring, E.; Carlyon, J.A. Anaplasma phagocytophilum Asp14 is an invasin that interacts with mammalian host cells via its $C$ terminus to facilitate infection. Infect. Immun. 2013, 81, 65-79. [CrossRef] [PubMed]

168. Seidman, D.; Ojogun, N.; Walker, N.J.; Mastronunzio, J.; Kahlon, A.; Hebert, K.S.; Karandashova, S.; Miller, D.P.; Tegels, B.K.; Marconi, R.T.; et al. Anaplasma phagocytophilum surface protein AipA mediates invasion of mammalian host cells. Cell. Microbiol. 2014, 16, 1133-1145. [CrossRef] [PubMed]

169. He, M.; Xu, W.; Zhang, L.; Liu, Z.; Zhu, J.; Li, Y.; Wu, S.; Niu, H. Identification of novel immunoreactive proteins and delineation of a specific epitope of Anaplasma phagocytophilum. Microb. Pathog. 2018, 125, 183-188. [CrossRef]

170. Fukui, Y.; Ohkawa, S.; Inokuma, H. First molecular detection and phylogenetic analysis of Anaplasma phagocytophilum from a clinical case of canine granulocytic anaplasmosis in Japan. Jpn. J. Infect. Dis. 2018, 71, 302-305. [CrossRef] [PubMed]

171. Dantas-Torres, F.; Otranto, D. Anaplasmosis. In Arthropod Borne Disease Switzerland; Marcondes, C.B., Ed.; Springer: Berlin/Heidelberg, Germany, 2017; pp. 215-222. 
172. Yancey, C.B.; Diniz, P.P.V.P.; Breitschwerdt, E.B.; Hegarty, B.C.; Wiesen, C.; Qurollo, B.A. Doxycycline treatment efficacy in dogs with naturally occurring Anaplasma phagocytophilum infection. J. Small Anim. Pract. 2018, 59, 286-293. [CrossRef]

173. Hansmann, Y.; Jaulhac, B.; Kieffer, P.; Martinot, M.; Wurtz, E.; Dukic, R.; Argemi, X.; De Martino, S. Value of PCR, serology, and blood smears for human granulocytic anaplasmosis diagnosis, France. Emerg. Infect. Dis. 2019, 25, 996. [CrossRef] [PubMed] 